Article

\title{
Gold Prospects in the Western Segment of the Russian Arctic: Regional Metallogeny and Distribution of Mineralization
}

\author{
Arkady A. Kalinin ${ }^{1, *}$, Oleg V. Kazanov ${ }^{2}$, Vladimir I. Bezrukov ${ }^{3}$ and Vsevolod Yu. Prokofiev ${ }^{4}$ \\ 1 Geological Institute, Kola Science Center, Russian Academy of Sciences, Apatity 184209, Russia \\ 2 N.M. Fedorovsky All-Russian Research Institute of Mineral Raw Materials, Moscow 119017, Russia; \\ okazanov@gmail.com \\ 3 A.P. Karpinsky Russian Geological Research Institute, S-Petersburg 199106, Russia; \\ vladimir_bezrukov@vsegei.ru \\ 4 Institute of Geology of Ore Deposits, Petrography, Mineralogy, and Geochemistry, Russian Academy of \\ Sciences, Moscow 119017, Russia; vpr2004@rabler.ru \\ * Correspondence: kalinin@geoksc.apatity.ru; Tel.: +7-921-663-68-36
}

Received: 18 December 2018; Accepted: 21 February 2019; Published: 26 February 2019

\begin{abstract}
Location of the deposits and occurrences of gold mineralization in metamorphic complexes of the Kola region is controlled by tectonic zones at the regional scale at the boundaries of major segments of the Fennoscandian Shield. Three zones are the most important: (1) the system of Neoarchean greenstone belts Kolmozero-Voron'ya-Ura-guba along the southern boundary of the Murmansk craton; (2) the suture, delineating the core of the Lapland-Kola orogeny in the north; and (3) the series of overthrusts and faults at the eastern flank of the Salla-Kuolajarvi belt. Gold deposits and occurrences are located within greenstone belts of Neoarchean and Paleoproterozoic age, and hosted by rocks of different primary compositions (mafic metavolcanics, diorite porphyry, and metasedimentary terrigenous rocks). The grade of metamorphism varies from greenschist to upper amphibolite facies, but the mineralized rocks are mainly lower amphibolite metamorphosed, close to the transition from greenschist to amphibolite facies. Gold deposits and occurrences in the northeastern part of the Fennoscandian Shield formed during two periods: the Neoarchean 2.7-2.6 Ga and the Paleoproterozoic 1.9-1.7 Ga. According to paleo-geodynamic reconstructions, these were the periods of collisional and accretionary orogeny in the region. Those Archean greenstone belts, which were reworked in the Paleoproterozoic (e.g., Strel'na and Tiksheozero belts), can contain gold deposits of Paleoproterozoic age.
\end{abstract}

Keywords: greenstone belt; gold; Kola Peninsula; Northern Karelia; rock alteration

\section{Introduction}

The western segment of the Russian Arctic (Kola region, for short below), covering the Murmansk region and Russian Northern Karelia, is not considered a gold district in Russia. Annual gold production in the Kola region is $0.1 \mathrm{t}$ [1]: gold, together with platinum group elements (PGEs), are byproducts of nickel-copper metallurgy, extracted by the Kola Mining-Metallurgical Company from the Pechenga nickel-copper ores (Figure 1), which contain $\sim 0.1 \mathrm{ppm}$ Au. Thus, gold is the third-most important component (after Pt and Pd) in low-sulfide PGE ore from layered mafic-ultramafic massifs in the region-the Fyodorovo-Pansky intrusion, and the Vuruchuaivench and Monchetundrovsky massifs (Figure 1). The gold content in regular low-sulfide ores varies from $0.08 \mathrm{ppm}$ (the Fyodorova Tundra deposit) [2] to $0.29 \mathrm{ppm}$ (the East Chuarvy deposit) [3]. Gold as an associated component of 
$\mathrm{Ni}-\mathrm{Cu}$ and PGE ores currently makes up more than $99 \%$ of the gold resources in the western segment of the Russian Arctic.

The distribution of gold resources in Northern Finland (Finnish Lapland), in the area adjacent to the Murmansk region and Russian Northern Karelia, differs significantly: gold in Ni-Cu (the Kevitsa deposit) and in the PGE low-sulfide deposits (the Ahmavaara, Kontijärvi, Siika-Kämä reef, etc.) only makes up 15\% of the gold resources in Finnish Lapland, and the other 85\% relates to gold deposits in metamorphic complexes within greenstone belts [4,5]. Presently in Northern Finland, there is one world class deposit (Suurikuusikko) with indicated and inferred resources of $260 \mathrm{t}$ and an annual production of 5.5-6 t Au [6], as well as a number of medium and small deposits, and dozens of prospective gold occurrences (Figure 1) [7].

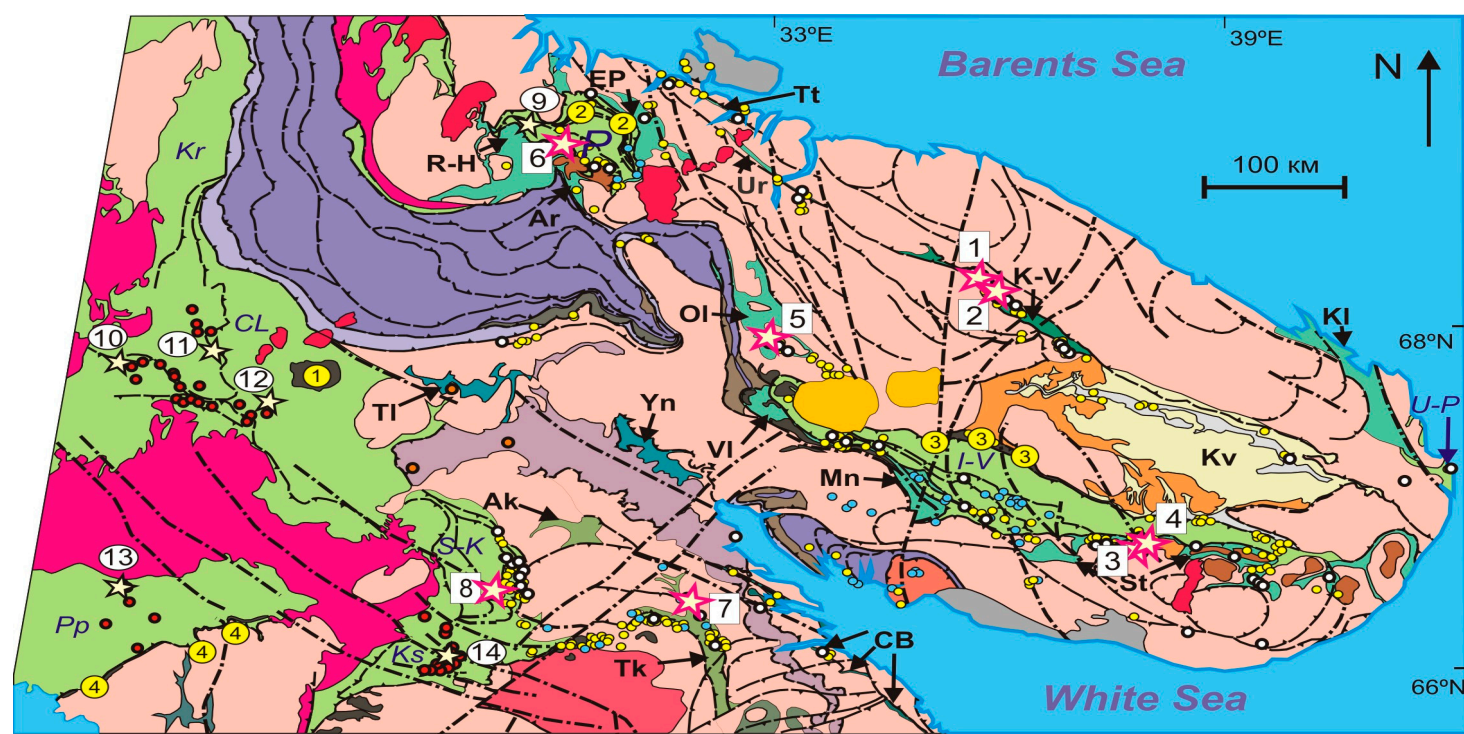

Neoproterozoic:

Riphean sediments

Paleoproterozoic:

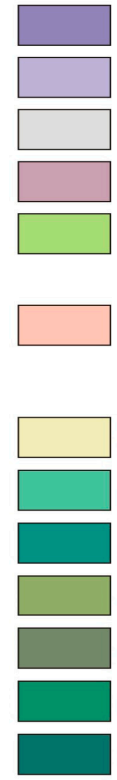

Paleoproterozoic granulite belts

Under-thrust mélange of granulite belts

Paleoproterozoic Keivian schist complex

Neoarchean Chupa belt schist

and gneiss complex

Paleoproterozoic greenschist belts (see
text for explanation of the abbreviations)

Neoarchean:

Gneiss-granite complex Greenstone belts(see text for
explanation of the abbreviations):

Metarhyodacite and metaandesite of the Keivan

volcanic-tectonic depression, $2.87-2.75 \mathrm{Ga}$

Riftogenic complex, 2.80-2.66 Ga

Complex of an active margin, 2.78-2.54 Ga

Greenstone belts, 2.84-2.76 Ga

Greenstone belts, $2.88-2.84 \mathrm{Ga}$

Kolmozero-Voron'ya paleosuture, $2.88-2.84 \mathrm{Ga}$

Central Belomorian paleosuture, 2.88-2.78 Ga
Igneous rocks:

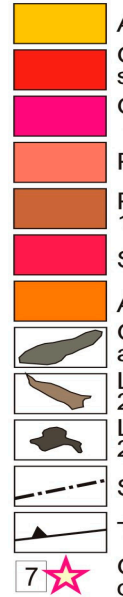

Alkaline massifs (PZ)

Granite, granodiorite, quartz monzonite syenite, 1.86-1.84 and 1.82-1.76 Ga Granite, trondhjemite, tonalite,

1.88-1.87 Ga

Porphyry granite, enderbite, 1.89-1.87 Ga

Plagiogranite, granodiorite, diorite, 1.89-1.87 Ga

Sanukitoid, 2.74-2.70 Ga

Alkaline granite, 2.76-2.75 Ga Granulite metamorphosed layered gabbroanorthosite massifs, 2.1-1.92 Ga Layered gabbro-anorthosite massifs Layered mafic-ultramafic massifs, $2.51-2.40 \mathrm{Ga}$

Steep dipping faults, shifts

Thrusts, upthrows

Gold deposits and occurrences, described in the paper (see text for

(12) Gold deposits in Finland and Norway

- Gold occurrences in Finland, after [12]

Points of gold mineralization in the Murmansk region: - $>1$ ppm

Points of silver mineralization

$\mathrm{Cu}-\mathrm{Ni}$ and PGE deposits with indicated gold resources: 1 - Kevitsa, 2 - the Pechenga group 3 - Fyodorova Tundra and Pansky massif
deposits, 4 - Pennikat, Narkaus, Konttijarvi deposits, 4 - Pe
Suhanko, et al.

Figure 1. Schematic tectonic-geological map (modified from Reference [8]), showing the locations of greenstone belts and gold mineralization in the northeastern part of the Fennoscandian Shield. 
Considering the similarity of lithological and geological structures of Northern Finland and the Kola region, the described difference in the distribution of gold resources (and deposits) can be explained, first of all, with different levels of exploration for gold, which are much lower in the Russian territory. This indicates a high probability of discovery of gold deposits in metamorphic complexes in the western segment of the Russian Arctic in future.

Data on certain gold occurrences in the Kola region can be found in the Russian geological literature, but no systematic information on gold mineralization in the Murmansk region and Northern Karelia has previously been published. For example, only two deposits (the Mayskoe quartz vein and Pellapahk porphyry) were noted in the paper by Krister Sundblad [9] devoted to gold deposits in Northern Europe. More gold deposits and occurrences were mentioned in Reference [10], published in 2012, those were the Mayskoe, Vorgovy, Olennoe, Oleninskoe, Nyal'm-1, and -2, Pellapahk; but the deposits and occurrences were not described in Reference [10] in detail.

During geological investigations carried out in the Kola region in the beginning of the 21st century, geological structures' prospective for gold mineralization were defined, new gold occurrences were found, and new data on the above-named deposits and occurrences obtained. Brief information about deposits and occurrences, studied during the last two decades, is provided in this paper.

The following terms are used throughout this study for the description of gold mineralization:

- A deposit-a concentration of minerals on the surface or underground with delineated mineralized bodies and indicated or inferred resources; quantity, quality, and bedding of the ore meet the exploitation requirements;

- An occurrence-mineralized rocks with gold content over 1 ppm for more than 1-m thickness according to core or trench sampling, with an undefined scale of mineralization and no contoured mineralized bodies;

- Points of gold mineralization-small occurrences with gold content more than $0.1 \mathrm{ppm}$ for thickness over $1 \mathrm{~m}$ in core or trench samples, or more than $1 \mathrm{ppm}$ in hand samples.

The following abbreviations are used below in the figures with the images of minerals:

Asp-arsenopyrite, $\mathrm{Cc}$-calcite, $\mathrm{C} p$-chalcopyrite, Di-diopside, $\mathrm{Gr}$-garnet, Grs-gersdorfite, $\mathrm{Hb}$-hornblende, Lo-löllingite, $\mathrm{Mr}$-marcasite, $\mathrm{Pl}$-plagioclase, Po-pyrrhotite, $\mathrm{Py}$-pyrite, $\mathrm{Qu}-$ quartz, Tit-titanite, Uy-Uytenbogaardtite, and Zo-zoisite.

\section{Materials and Methods}

Data on gold occurrences and points of mineralization (Figure 1) were collected in the Fund of Geological Information on Mineral Resources in the Murmansk Region from the open access reports on the results of geological mapping and exploration, carried out in the Kola region by state geological surveys and mining companies, beginning in the 1930s and continuing up to the present. Data for gold deposits and occurrences in the northern part of Finland (Figure 1) were taken from the database FINGOLD [7], which contains information on occurrences of gold mineralization with $>1 \mathrm{ppm}$ Au for intervals over $1 \mathrm{~m}$ in trench and/or core samples.

The authors of the present paper took part in fieldwork connected with the exploration for gold during different time periods from the 1970s to 2017, and visited all the described gold occurrences and deposits, and collected the necessary materials to study the geology, petrography, geochemistry, and mineralogy of the deposits. The only exception was the Olenegorsk group of banded iron formations deposits (BIFs), where information on this gold mineralization was based on published data. Schematic geological maps of gold deposits and occurrences given in this paper were compiled by the authors themselves, if there are no references cited in the figure captions.

The following abbreviations are used in Figure 1: Paleoproterozoic greenschist belts (letters in italics), Polmak-Pasvik-Pechenga-Imandra-Varzuga belt system: P-Pechenga belt, I-V-Imandra-Varzuga belt, U-P-Ust'-Ponoy belt; Lapland-Karelia belt system: Kr-Karasjok, CL-Central Lapland belt, S-K-Salla-Kuolajarvi belt, Ks-Kuusamo belt; Pp-Perapohja belt. 
Neoarchean greenstone belts (letters in bold): K-V-Kolmozero-Voron'ya belt, CB-Central Belomorian belt, Tk-Tiksheozero belt, Ak-Alakurti, Yn-Yona belt, Tl-Tulppio-Kareka Tundra belt, St-Strel'na belt, Mn-Munozero, Vl-Vochelambina, Ol-Olenegorsky belt, R-H-Runijoki-Hihnajarvi, Ar-Allarechka belt, EP-East-Pechenga belt (NE frame of the Pechenga belt), Tt-Titovka, Ur-Ura-guba, Kl-Kachalovsky, Kv-Keivan volcanic-tectonic depression. Gold deposits and occurrences: 1-Oleninskoe, 2-Nyal'm, 3-Sergozero, 4-Vorgovy, 5-Olenegorsk BIF deposits, 6-Porojarv, 7-iKichany, 8-Mayskoe, 9-Gjeddevanett, 10-Saattopora, 11-Suurikuusikko, 12-Pahtavaara, 13-Rompas and Rajapalot, 14-Juomasuo.

Investigations of wallrock alteration, metasomatic zonation, and determination of pre-ore, gold-related, and post-ore mineral assemblages in altered rocks were based on the study of rocks in the outcrops and in drillcore, on examination of mineral relations in thin and polished sections, as well as on the results of assays of primary and altered rocks.

The samples were assayed for major (rock-forming) elements in the chemical laboratory of the Geological Institute, Kola Science Centre, Russian Academy of Sciences, with flame atomic absorption spectrometry (FAAS). Data on minor elements, which determined the geochemical characteristics of the deposits, were obtained by ICP-MS in IRGIREDMET (Irkutsk) and in the Institute of Geology and Geochemistry of the Ural Branch of the Russian Academy of Sciences, Ekaterinburg.

Gold content in the samples from the Sergozerskoe, Vorgovy, and Kichany occurrences was determined in IRGIREDMET with ICP-MS after fire assay pre-concentration of precious metals; the data on gold content in the samples from the Oleninskoe deposit and Porojarvi occurrence were obtained in the chemical laboratory of the Geological Institute, Kola Science Centre RAS by FAAS with pre-concentration of PGE, gold, and silver with p-alkylaniline and oil sulfides. Data on gold grades in other deposits were taken from published papers and/or public releases by mining companies.

Mineral composition of the ores was studied in polished sections with reflected light microscope Axioplan 2 Imaging (Karl Zeiss, Jena, Germany) and with the electron microscope LEO-1450 (Karl Zeiss, Jena, Germany) in the Geological Institute of the Kola Science Center. Preliminary estimation of the composition of mineral species was done with the energy-dispersive system Bruker XFlash-5010. Microprobe analysis (MS-46, CAMECA, France, 22 kV; 30-40 nA, standards (analytical lines): $\mathrm{Fe}_{10} \mathrm{~S}_{11}$ $(\mathrm{FeK} \alpha, \mathrm{SK} \alpha), \mathrm{Bi}_{2} \mathrm{Se}_{3}(\mathrm{BiM} \alpha, \mathrm{SeK} \alpha), \operatorname{LiNd}\left(\mathrm{MoO}_{4}\right)_{2}(\mathrm{MoL} \alpha), \mathrm{Co}(\mathrm{CoK} \alpha), \mathrm{Ni}(\mathrm{NiK} \alpha), \operatorname{Pd}(\operatorname{PdL} \alpha)$, $\operatorname{Ag}(\operatorname{AgL} \alpha)$, Te $(\operatorname{TeL} \alpha), A u(\operatorname{AuL} \alpha))$ was performed for grains larger than $20 \mu \mathrm{m}$. Identification of rare mineral phases was verified with X-ray analysis in the Geological Institute of the Kola Science Center.

Fluid inclusions were studied with a Linkam THMSG-600 freezing/heating stage (Linkam Scientific, Epsom, UK) equipped with an Olympus BX51 optical microscope, video camera, and computer at the Institute of Geology of Ore Deposits, Mineralogy, Geochemistry, and Petrography, Russian Academy of Sciences, Moscow, Russia. The composition of salts in fluid inclusions was estimated from the eutectic temperature [11], and the salinity was estimated from the final melting temperatures of ice according to the experimental data of the $\mathrm{NaCl}-\mathrm{H}_{2} \mathrm{O}$ system [12]. The salinity of the aqueous solution in the $\mathrm{CO}_{2}-\mathrm{H}_{2} \mathrm{O}$ inclusions was estimated from the melting temperature $\mathrm{CO}_{2}$ hydrates [13]. The $\mathrm{CO}_{2}$ and $\mathrm{CH}_{4}$ concentrations were estimated from volumetric ratios of phases and the densities of $\mathrm{CO}_{2}$ and $\mathrm{CH}_{4}$ in gas phase. Pressure was determined for immiscible fluids from the intersection of the isochore and isotherm. The salinity and pressure of the fluid was calculated with the FLINCOR program [14].

\section{Geological Setting}

The area under consideration in this study (shown with the blue rectangle in Figure 2A) occupies the northwestern part of the Fennoscandian Shield, including the Murmansk craton, Kola Province, northern part of the Belomorian mobile belt, and a small part of the Karelian craton (Figure 2A) [15].

The Murmansk craton is composed of diverse granite gneisses and granitoids, which contain some xenoliths of Archean supracrustal rocks. 
The Kola Province is the Archean tectonic collage of the Kola-Norwegian, Keivy, Sosnovka, and Kolmozero-Voron'ya terranes. The terranes consist of the Archean greenstone, schist, paragneiss, granulite, and granite-gneiss complexes that underwent structural deformation and metamorphism in the Archean and Paleoproterozoic, except the Kola-Norwegian Terrane, which almost escaped the Paleoproterozoic process.

The Belomorian Mobile belt is made up largely of Meso- and Neoarchean granite gneisses, greenstone rocks, and paragneiss complexes. The province is distinguished by intense repeated deformations and high- and moderate-pressure metamorphic events that occurred in both the Neoarchean and Paleoproterozoic.

The Kola and Belomorian provinces evolved in structural deformation and metamorphism in the Paleoproterozoic, being elements of the Paleoproterozoic Lapland-Kola collisional Svecofennian (1.95-1.75 Ga) orogen (Figure 2A). The Pechenga-Imandra-Varzuga and Lapland-Kola collisional sutures are localized in the central part of this orogen (Figure 2B).

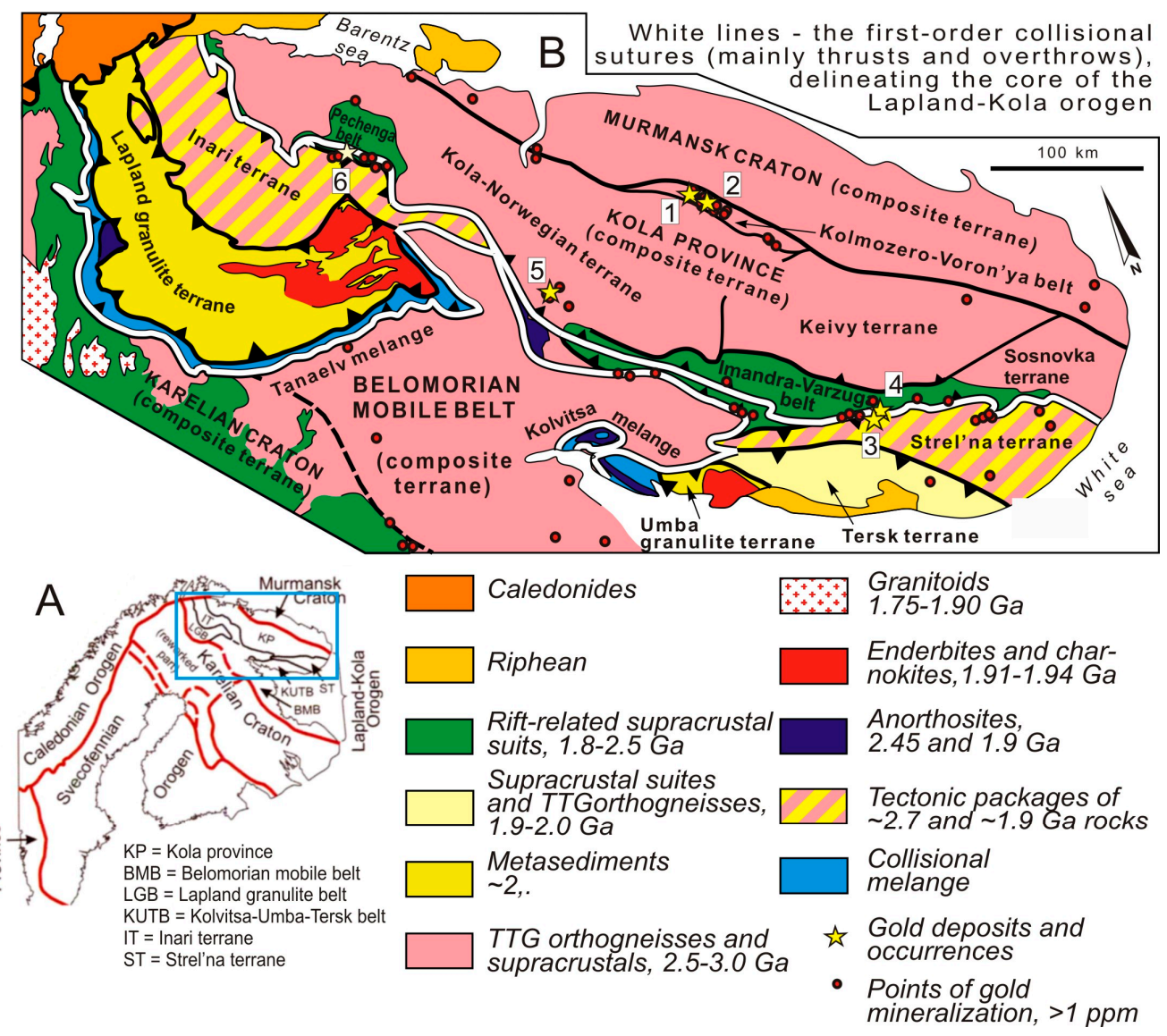

Figure 2. Schematic tectonic map of the Fennoscandian Shield (A) and of the Kola region and adjacent regions of Northern Fennoscandia (B) [15].

The Karelian craton is a classic Neoarchaean granite-greenstone province, containing a few remnants of the Mesoarchean crust. It is cut by a series of Palaeoproterozoic rifts and related layered mafic intrusions.

The Paleoproterozoic volcanic-sedimentary rocks of 1.8-2.5 Ga age form two rift-related systems of greenschist belts. The Polmak-Pasvik-Pechenga-Imandra-Varzuga belt system stretches southwest from Norway across the Kola Peninsula to the White Sea for about $500 \mathrm{~km}$ along the southern boundary of the Kola Province. The largest parts of this system are the Pechenga and Imandra-Varzuga belts (Figure 1). The Lapland-Karelian belt system can be traced for more than $1000 \mathrm{~km}$ along the northern boundary of the Karelian craton from Norway across Finnish Lapland and Russian 
Karelia. In the northern part of the Fennoscandian Shield the system consists of the Karasjok, Lapland, Salla-Kuolajarvi, and Kuusamo belts (Figure 1).

\section{Brief Information on Gold Deposits in the Western Segment of the Russian Arctic}

In the Murmansk region and Northern Karelia there are four minor gold deposits with indicated and inferred resources (not complying with NI 43-101 and other international and national Codes). Two of them-the Oleninskoe (10 $\mathrm{t} \mathrm{Au}$ ) and Nyal'm (7.5 t) —are located in the Kolmozero-Voron'ya greenstone belt, the Sergozerskoe (13 t Au) —in the Strel'na belt, and the Mayskoe $(0.122 \mathrm{t} \mathrm{Au})$ in the Salla-Kuolajarvi belt (Figures 1 and 2). The latter is the only gold deposit ever developed in the region (51 kg mined between 1998-2000) [16]. Gold occurrences are known in the Strel'na belt (Vorgovy), in the Pechenga belt (Porojarvi), and in the Tiksheozero belt (Kichany). Gold mineralization in the iron-producing BIF deposits Olenegorskoe and Kirovogorskoe have a statute of gold occurrences as well.

\subsection{Gold Deposits in the Kolmozero-Voron'ya Greenstone Belt}

Two small gold deposits (Oleninskoe and Nyal'm) and dozens of occurrences and points of mineralization were found in the northwestern part of the Neoarchean greenstone belt Kolmozero-Voron'ya, which separates two major blocks of the Fennoscandian Shield-the Murmansk craton and the Kola-Norwegian terrane (Figures 1 and 2). Both deposits are located in the axial part of the belt and relate to the stratigraphic sequence of the Oleny Ridge amphibolite.

The Oleninskoe deposit (\#1 in Figure 1) is located at the northwestern thinning of the Oleny Ridge amphibolite strata in a shear zone of northwest strike. The amphibolite and high-alumina metasedimentary schist host numerous granodiorite quartz porphyry dykes 0.1-6.0-m thick with the bedding concordant to the wallrocks (Figure 3). The latest rocks in the deposit area are granite-pegmatite veins, which cut all rocks, including those mineralized.

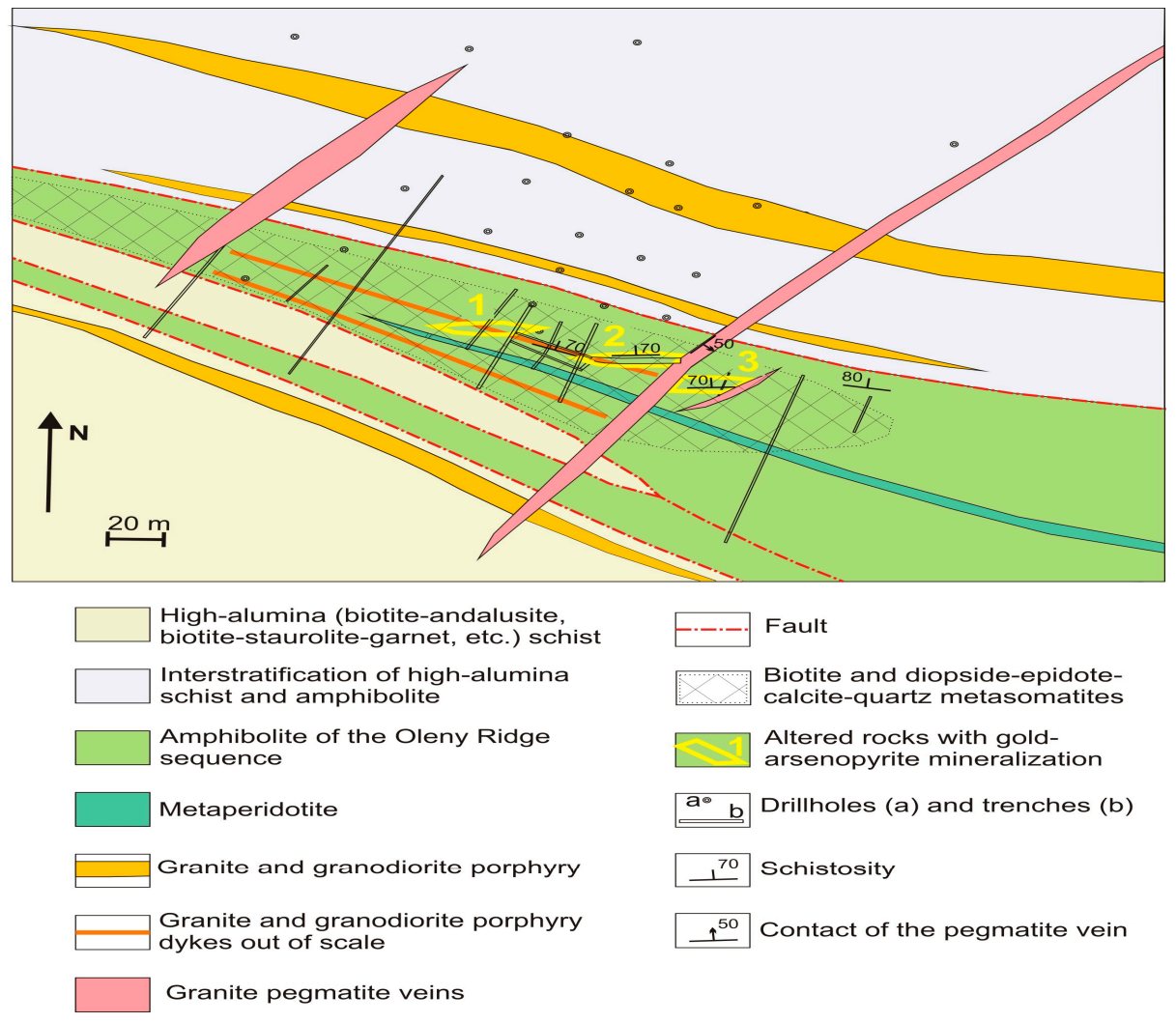

Figure 3. Schematic geological map of the Oleninskoe gold deposit. 
The rocks are intensely altered (except pegmatite), the alteration zone is 50-m thick and traced along the strike for 200-250 m. Pre-ore alteration processes, covering the whole zone of alteration, were biotitization (potassium metasomatism) and formation of diopside-zoisite-carbonate, diopside-zoisite-garnet mineral assemblages (calcium metasomatism) in the amphibolite (Figure 4, Table 1).
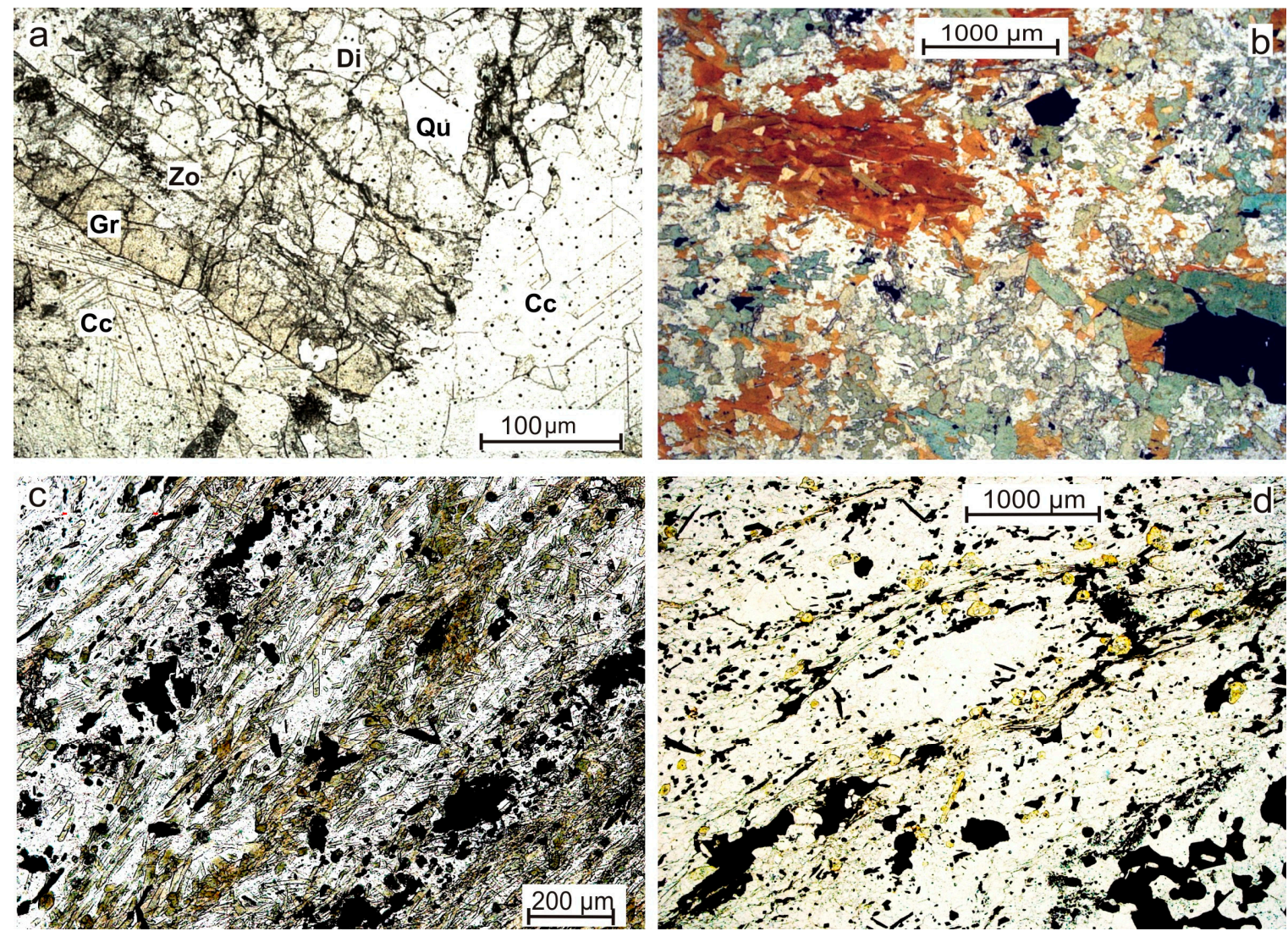

Figure 4. Altered rocks from the Oleninskoe deposit. Thin sections photos, transparent light, one polarizer: (a) diopside-zoisite-calcite-garnet metasomatite; (b) biotitizated hornblendite; and (c) and (d) quartz-tourmaline metasomatic rock: (c) after granite porphyry, with arsenopyrite dissemination and (d) after hornblende amphibolite, with pyrrhotite-arsenopyrite mineralization.

Gold-related alteration was the formation of quartz-muscovite-oligoclase, quartz-tourmaline, and quartz metasomatic rocks after both amphibolite and quartz porphyry (Table 2). Quartz-rich metasomatic rocks form an echelon-like series of lenticular bodies, cutting general schistosity in the host rocks at an acute angle of $10-15^{\circ}$ (Figure 3), and control distribution of the gold-arsenopyrite mineralization. The lenses are up to $3.5-\mathrm{m}$ thick ( $1.5 \mathrm{~m}$ on the average) with the length up to $50 \mathrm{~m}$.

Arsenopyrite, pyrrhotite, and ilmenite are the most abundant ore minerals, which present in all altered rocks. Minor sulfides are chalcopyrite, sphalerite, and pentlandite. Quartz-tourmaline and quartz metasomatic rocks in lens 2 contain rich $\mathrm{Pb}-\mathrm{Ag}-\mathrm{Sb}$ mineralization (galena, freibergite, dyscrasite, boulangerite, semseyite, diaphorite, pyrargyrite, and other $\mathrm{Sb}$-sulfosalts of $\mathrm{Pb}, \mathrm{Ag}$, and $\mathrm{Cu}$, etc.-totalling more than 40 mineral phases [17]). Ilmenite in quartz metasomatic rocks is partly replaced by rutile along the grain boundaries. 
Table 1. Chemical composition of the mineralized rocks of the Oleninskoe deposit, mas.\%.

\begin{tabular}{|c|c|c|c|c|c|c|c|c|c|c|c|c|c|c|}
\hline Sample \# & AK-713 & AK-708 & AK-716 & AK-715 & AK-703 & AK-704a & AK-706 & VP-10 & AK-710 & $114-79$ & $114 b-79$ & AK-707 & AK-705 & AK-24 \\
\hline $\mathrm{SiO}_{2}$ & 47.20 & 51.19 & 49.94 & 47.12 & 49.24 & 46.90 & 71.56 & 69.53 & 64.22 & 76.52 & 69.11 & 62.38 & 89.12 & 82.27 \\
\hline $\mathrm{TiO}_{2}$ & 0.75 & 1.21 & 0.67 & 0.98 & 1.37 & 1.17 & 0.34 & 0.23 & 0.97 & 0.44 & 0.68 & 0.28 & 0.05 & 0.11 \\
\hline $\mathrm{Al}_{2} \mathrm{O}_{3}$ & 12.20 & 11.61 & 17.00 & 15.39 & 12.89 & 12.31 & 14.69 & 16.20 & 11.91 & 8.22 & 10.64 & 2.71 & 1.62 & 2.11 \\
\hline $\mathrm{Fe}_{2} \mathrm{O}_{3}$ & 0.84 & 1.76 & 0.00 & 3.39 & 1.68 & 2.60 & 0.00 & 0.48 & 1.62 & 1.51 & 4.90 & 7.99 & 0.00 & 5.31 \\
\hline $\mathrm{FeO}$ & 10.64 & 10.81 & 4.40 & 8.30 & 11.35 & 10.38 & 2.38 & 1.36 & 5.18 & 4.14 & 1.78 & 6.39 & 3.01 & 2.47 \\
\hline $\mathrm{MnO}$ & 0.23 & 0.21 & 0.11 & 0.27 & 0.22 & 0.25 & 0.03 & 0.03 & 0.02 & 0.04 & 0.03 & 0.02 & 0.05 & 0.03 \\
\hline $\mathrm{MgO}$ & 11.20 & 5.37 & 1.84 & 5.18 & 6.49 & 5.82 & 1.18 & 1.18 & 0.19 & 1.41 & 1.22 & 0.43 & 1.17 & 0.86 \\
\hline $\mathrm{CaO}$ & 12.33 & 14.31 & 19.50 & 12.93 & 10.71 & 12.32 & 2.50 & 1.74 & 0.39 & 2.35 & 2.83 & 0.65 & 2.02 & 1.14 \\
\hline $\mathrm{Na}_{2} \mathrm{O}$ & 1.68 & 1.14 & 1.31 & 1.44 & 1.13 & 0.98 & 4.89 & 6.28 & 2.28 & 2.14 & 3.24 & 0.49 & 0.11 & 0.44 \\
\hline $\mathrm{K}_{2} \mathrm{O}$ & 0.10 & 0.21 & 0.07 & 1.04 & 1.17 & 1.33 & 1.01 & 1.56 & 1.94 & 0.60 & 0.47 & 0.26 & 0.07 & 0.19 \\
\hline $\mathrm{H}_{2} \mathrm{O}^{-}$ & 0.08 & 0.04 & 0.16 & 0.03 & 0.14 & 0.39 & 0.11 & 0.00 & 0.44 & 0.29 & 0.24 & 0.67 & 0.00 & 0.22 \\
\hline $\mathrm{H}_{2} \mathrm{O}^{+}$ & 2.42 & 1.06 & 1.39 & 1.14 & 1.57 & 1.69 & 0.73 & 0.83 & 2.60 & 1.15 & 0.67 & 3.86 & 0.28 & 0.28 \\
\hline S & 0.07 & 0.60 & 0.05 & 1.37 & 1.08 & 2.46 & 0.07 & 0.01 & 1.15 & 1.95 & 2.26 & 3.57 & 0.04 & 2.20 \\
\hline $\mathrm{P}_{2} \mathrm{O}_{5}$ & 0.05 & 0.10 & 0.05 & 0.06 & 0.08 & 0.11 & 0.07 & 0.06 & 0.42 & 0.01 & 0.00 & 0.46 & 0.03 & 0.13 \\
\hline $\mathrm{CO}_{2}$ & $<0.10$ & $<0.10$ & 3.32 & 0.11 & $<0.10$ & $<0.10$ & $<0.10$ & 0.00 & $<0.10$ & 0.06 & 0.00 & $<0.10$ & $<0.10$ & 0.02 \\
\hline $\mathrm{F}$ & 0.019 & 0.016 & 0.014 & 0.01 & 0.098 & 0.057 & 0.017 & 0.000 & 0.014 & 0.019 & 0.000 & 0.010 & 0.011 & 0.018 \\
\hline $\mathrm{Cl}$ & 0.009 & 0.009 & 0.011 & 0.01 & 0.009 & 0.009 & 0.011 & n.a. & 0.013 & n.a. & n.a. & 0.010 & 0.007 & n.a. \\
\hline Total & 99.85 & 99.66 & 99.85 & $98.81 *$ & 99.34 & $98.84 *$ & 99.62 & 99.51 & $93.38 *$ & 100.86 & $98.08 *$ & $90.19 *$ & $97.60 *$ & $97.80 *$ \\
\hline $\mathrm{Ag}(\mathrm{ppm})$ & 0.26 & 1.46 & 0.46 & 1.68 & 2.3 & 18.05 & 0.8 & n.a. & 20.72 & n.a. & n.a. & 96.56 & 0.086 & n.a. \\
\hline $\mathrm{Au}(\mathrm{ppm})$ & 0.016 & 0.009 & $<0.004$ & 1.04 & 0.49 & 1.27 & $<0.004$ & n.a. & 3.29 & n.a. & n.a. & 3.16 & $<0.004$ & n.a. \\
\hline $\mathrm{Pd}(\mathrm{ppm})$ & $<0.004$ & $<0.004$ & $<0.004$ & n.a. & $<0.004$ & $<0.004$ & $<0.004$ & n.a. & $<0.004$ & n.a. & n.a. & 0.019 & $<0.004$ & n.a. \\
\hline $\mathrm{Cu}$ & 0.01 & 0.012 & $<0.005$ & 0.015 & 0.016 & 0.026 & $<0.005$ & n.a. & 0.018 & n.a. & n.a. & 0.029 & $<0.01$ & n.a. \\
\hline $\mathrm{Ni}$ & 0.028 & 0.009 & 0.009 & 0.019 & 0.008 & 0.01 & 0.005 & n.a. & 0.006 & n.a. & n.a. & 0.013 & 0.014 & n.a. \\
\hline Co & $<0.005$ & $<0.005$ & $<0.005$ & $<0.005$ & $<0.005$ & $<0.005$ & $<0.005$ & n.a. & $<0.005$ & n.a. & n.a. & $<0.005$ & $<0.01$ & n.a. \\
\hline
\end{tabular}

* The deficit appears due to high content of arsenopyrite mineralization, the samples were not assayed for As; n.a. = not assayed; AK-713, AK-708-amphibolite; AK-716-diopside-epidote-calcite-garnet metasomatite (skarnoid) after amphibolite; AK-715, 703, 704a—biotitized amphibolite; VP-10, AK-706-granite porphyry (dyke); AK-710, 114-79, 114b-79-quartz-sericite-tourmaline metasomatite; AK-707, AK-705, AK-24—quartz metasomatite. 
Four types of minerals of $\mathrm{Au}-\mathrm{Ag}$ series were recognized: 1-electrum 25-32 mas.\% $\mathrm{Au}$ in association with arsenopyrite, löllingite, and pyrrhotite (Figure 5a); 2-electrum 33-47 mas.\% Au in intergrowths with galena, dyscrasite, and sulfosalts; 3-gold (78-95 mas.\% Au) in quartz; 4-native silver ( $<7$ mas. $\% \mathrm{Au})$ in the crust of weathering of the ore (Table 3). Types 1 and 3 are widespread in the deposit, and 2 and 4 relate only to the quartz and quartz-tourmaline rocks rich in $\mathrm{Pb}-\mathrm{Ag}-\mathrm{Sb}$.

Gold and silver content are not stable even within one and the same grain of electrum: some grains are zonal with the outer parts enriched in Ag (Figure 6a,b), other grains are cross-cut by Au-rich "veinlets" (Figure 6c).

Table 2. General characteristics of gold deposits in the Kolmozero-Voron'ya greenstone belt.

\begin{tabular}{|c|c|c|c|}
\hline \multicolumn{2}{|c|}{ Deposit } & Oleninskoe & Nyal'm \\
\hline \multicolumn{2}{|c|}{ Tectonic structure } & $\begin{array}{l}\text { Intersection of NW shear zone and a } \\
\text { sub-meridional fault }\end{array}$ & $\begin{array}{l}\text { Tectonized contacts of porphyry } \\
\text { intrusion }\end{array}$ \\
\hline \multicolumn{2}{|c|}{ Host rocks } & $\begin{array}{l}\text { Amphibolite, quartz porphyry dykes } \\
(\sim 2.83 \mathrm{Ga})\end{array}$ & $\begin{array}{l}\text { Gabbrodiorite-diorite-granodiorite } \\
\text { porphyry }(\sim 2.83 \mathrm{Ga})\end{array}$ \\
\hline \multicolumn{2}{|c|}{ Regional metamorphism } & \multicolumn{2}{|c|}{$\begin{array}{l}\text { (1) Neoarchean: } 2.6-2.9 \mathrm{Ga} \text {, lower amphibolite } \mathrm{T} \sim 600^{\circ} \mathrm{C}, \mathrm{P}=3-4 \mathrm{kbar} \text {; } \\
\text { (2) Paleoproterozoic: } 1.8-1.9 \mathrm{Ga} \text {, lower amphibolite } \mathrm{T} \sim 530^{\circ} \mathrm{C}, \mathrm{P}=5.0-5.5 \mathrm{kbar} \text {. }\end{array}$} \\
\hline \multirow{3}{*}{$\begin{array}{l}\text { Alteration, assemblages } \\
\text { of new formed minerals }\end{array}$} & -pre-ore & $\begin{array}{c}\text { K-Ca: } \\
\text { Biotite, diopside-epidote-carbonate }\end{array}$ & $\begin{array}{c}\text { K-Ca-(Si) } \\
\text { Beresite } \\
\text { (quartz-carbonate-muscovite), } \\
\text { biotite-epidote }\end{array}$ \\
\hline & -gold-related & $\begin{array}{l}\text { Si-B-(K) } \\
\text { Quartz-tourmaline-muscovite, } \\
\text { quartz-tourmaline, quartz }\end{array}$ & $\begin{array}{c}\mathrm{CO}_{2}-\mathrm{Si} \\
\text { Stockwork of quartz-carbonate } \\
\text { veinlets }\end{array}$ \\
\hline & -post-ore & Near-pegmatite: biotite and holmquistite & Not defined \\
\hline \multicolumn{2}{|c|}{ Mineralized bodies } & $\begin{array}{l}\text { Mineralized lenses up to } 3.5 \times 50 \mathrm{~m} \text {. The } \\
\text { best sections: } 83.8 \mathrm{ppm} \text { for } 2.2 \mathrm{~m} \text { in } \\
\text { drillhole \#BF- } 28 \text { and } 88.6 \mathrm{ppm} \text { for } 1.5 \mathrm{~m} \text { in } \\
\text { BF-45 [18]; average grade } 7.6 \mathrm{ppm} \mathrm{Au}\end{array}$ & $\begin{array}{c}\text { Mineralized stockwork up to } 15-\mathrm{m} \\
\text { thick with weighted average } 1.2 \mathrm{ppm} \\
\mathrm{Au} \text {. The best intersections are } 0.93 \\
\text { ppm Au for } 32.8 \mathrm{~m} \text { and } 1.77 \mathrm{ppm} \text { for } \\
18.4 \mathrm{~m} \text { in two intervals in drillhole } \\
\text { \#BF-107 [18] }\end{array}$ \\
\hline \multicolumn{2}{|c|}{ Texture of mineralization, sulfide content (\%) } & Disseminated, veinlet-disseminated, 1-15 & Disseminated, $1-3$ \\
\hline \multicolumn{2}{|c|}{ Main ore minerals } & Arsenopyrite, pyrrhotite, ilmenite & Pyrrhotite \\
\hline \multicolumn{2}{|c|}{ Minor ore minerals } & $\begin{array}{c}\text { Chalcopyrite, sphalerite, galena, } \\
\text { freibergite, sheelite, pyrite, Sb-sulfosalts, } \\
\text { löllingite, dyscrasite, electrum, } \\
\text { uytenbogaardtite, aurostibite, petzite, } \\
\text { chlorargyrite. }\end{array}$ & $\begin{array}{l}\text { Chalcopyrite, pyrite, cobaltite, } \\
\text { ilmenite, arsenopyrite }\end{array}$ \\
\hline \multicolumn{2}{|c|}{ Geochemical association } & $\begin{array}{c}\mathrm{Au}-\mathrm{As}-\mathrm{Ag}(\mathrm{Sb}-\mathrm{Cu}-\mathrm{Pb}-\mathrm{Zn}-\mathrm{B}-\mathrm{W}) \\
\mathrm{Au} / \mathrm{Ag}<0.2\end{array}$ & $\begin{array}{c}\mathrm{Au}-\mathrm{As} \\
\mathrm{Au} / \mathrm{Ag}>1\end{array}$ \\
\hline \multicolumn{2}{|c|}{ Age of mineralized rocks } & $\begin{array}{l}\text { Neoarchean-later than } 2.83 \mathrm{Ga} \text {, but } \\
\text { before } 2.45 \mathrm{Ga}\end{array}$ & Neoarchean(?)-later than $2.83 \mathrm{Ga}$ \\
\hline Gold characterist & fineness & $\begin{array}{l}4 \text { types of } \mathrm{Au}-\mathrm{Ag} \text { alloys: } 1) \text { electrum } \\
(25-32 \text { mas. } \% \mathrm{Au}) \text { with arsenopyrite; } 2) \\
\text { electrum }(33-47 \% \mathrm{Au}) \text { with galena and } \\
\text { Sb-sulfosalts; } 3) \text { gold }(78-95 \% \mathrm{Au}) \text { in } \\
\text { quartz; } 4) \text { silver }(<7 \% \mathrm{Au}) \text { in the } \\
\text { weathered rocks. }\end{array}$ & $\begin{array}{l}\text { Grains up to } 1.0 \mathrm{~mm} \text { in } \\
\text { carbonate-quartz veinlets. The gold } \\
\text { fineness is } 890-940 .\end{array}$ \\
\hline
\end{tabular}

Other gold minerals in the Oleninskoe are gold-bearing dyscrasite (grains up to $1 \mathrm{~mm}$ ) (Figure 6), aurostibite, petzite, calaverite (inclusions $<10 \mu \mathrm{m}$ in electrum of the 2nd type), and uytenbogaardtite, which forms rims around grains of electrum (Figure $5 b$ ).

The gold content in dyscrasite varies from 0 to $17 \mathrm{wt} . \%$ (Table 4), some grains are zonal with the outer parts enriched in $\mathrm{S}$ and poor in Au (Figure 6c). 

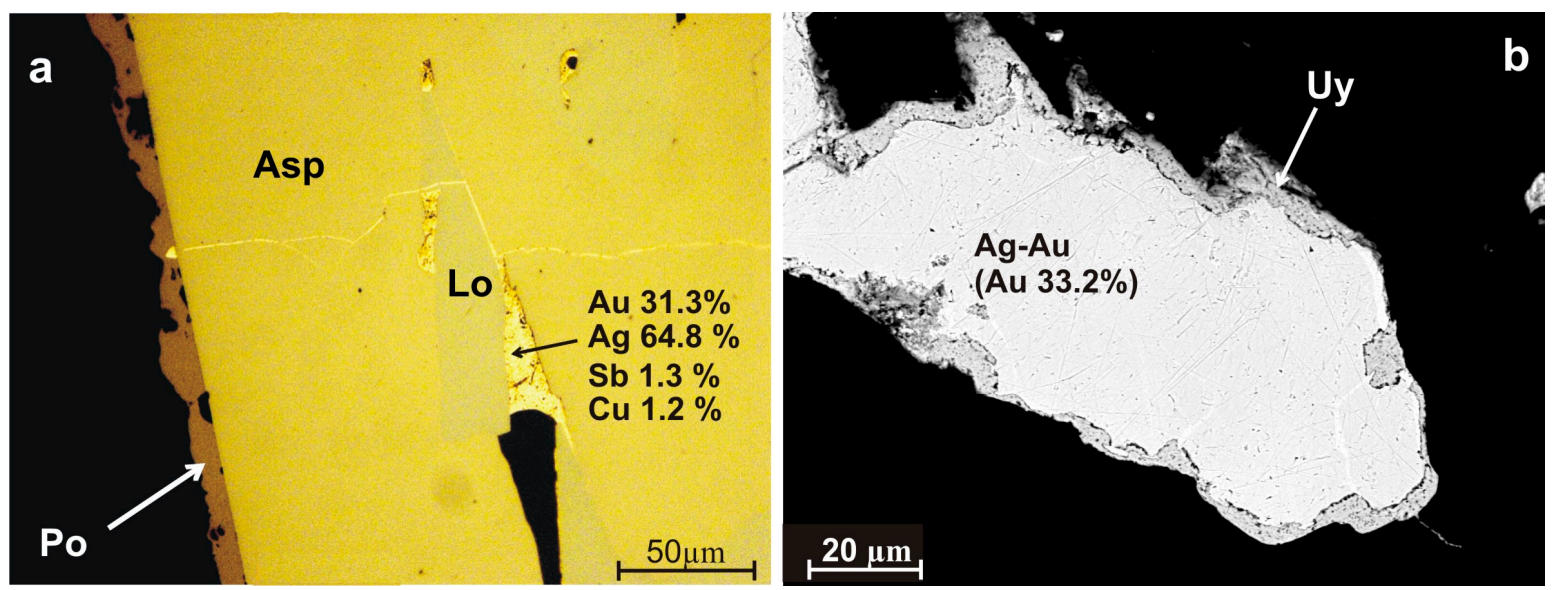

Figure 5. (a) Electrum of the 1st type at the boundary arsenopyrite (Asp)-löllingite (Lo) and in fissures in arsenopyrite, reflected light, one polarizer; (b) back scattered electron image of uytenbogardtiite, replacing electrum.

Table 3. Electron microprobe data in wt.\% for native gold and silver from the Oleninskoe and Nyal'm (sample \# 62.8-107) deposits.

\begin{tabular}{|c|c|c|c|c|c|c|c|c|c|c|c|}
\hline Sample \# & Type & $\mathrm{Fe}$ & $\mathrm{Ni}$ & $\mathrm{Cu}$ & $\mathrm{Pb}$ & Ag & $\mathrm{Au}$ & $\mathrm{Sb}$ & As & $S$ & Total \\
\hline 090 & 1 & 1.20 & n.a. & 0.03 & $<0.01$ & 72.35 & 25.52 & 0.05 & 1.61 & 0.14 & 100.91 \\
\hline $9014-2$ & 1 & 0.22 & 0.05 & 1.21 & n.a. & 64.77 & 31.34 & 1.27 & 0.53 & 0.27 & 99.66 \\
\hline AK-707-1 & 1 & 0.12 & n.a. & n.a. & 0.88 & 77.49 & 20.87 & n.a. & n.a. & 0.59 & 99.94 \\
\hline 700 & 2 & 0.01 & n.a. & $<0.01$ & $<0.01$ & 61.79 & 33.63 & 1.78 & $<0.01$ & $<0.01$ & 97.20 \\
\hline 700 & 2 & 0.01 & n.a. & 0.01 & $<0.01$ & 55.13 & 37.29 & 2.41 & $<0.01$ & $<0.01$ & 94.86 \\
\hline $711-8-23(C)$ & 2 & $<0.01$ & n.a. & $<0.01$ & n.a. & 32.14 & 62.84 & 0.29 & $<0.01$ & n.a. & 95.28 \\
\hline $711-8-23(\mathrm{R})$ & 2 & $<0.01$ & n.a. & $<0.01$ & n.a. & 51.68 & 42.46 & 0.34 & $<0.01$ & n.a. & 94.48 \\
\hline $711-2-1(\mathrm{C})$ & 2 & $<0.01$ & n.a. & $<0.01$ & n.a. & 52.22 & 41.14 & 1.81 & $<0.01$ & n.a. & 95.17 \\
\hline 711-2-1(R) & 2 & $<0.01$ & n.a. & $<0.01$ & n.a. & 37.07 & 58.10 & 0.65 & $<0.01$ & n.a. & 95.81 \\
\hline AK-711A-1 & 2 & 0.14 & n.a. & n.a. & n.a. & 39.61 & 59.17 & n.a. & n.a. & 1.04 & 99.96 \\
\hline 700 & 2 & 0.03 & n.a. & 0.02 & $<0.01$ & 39.35 & 54.99 & 0.71 & $<0.01$ & $<0.01$ & 95.09 \\
\hline 284 & 2 & 0.01 & $<0.01$ & $<0.01$ & n.a. & 34.58 & 61.16 & 0.49 & 0.08 & $<0.01$ & 96.32 \\
\hline 284 & 2 & 0.02 & $<0.01$ & $<0.01$ & n.a. & 24.16 & 73.20 & 0.16 & 0.08 & $<0.01$ & 97.62 \\
\hline $\mathrm{K}-13 \mathrm{C}-29 / 1$ & 3 & n.a. & n.a. & n.a. & n.a. & 21.80 & 77.87 & n.a. & n.a. & n.a. & 99.67 \\
\hline K-505.7 & 3 & n.a. & n.a. & 0.05 & n.a. & 12.77 & 86.65 & n.a. & n.a. & n.a. & 99.47 \\
\hline K-027-12/1 & 3 & n.a. & n.a. & n.a. & n.a. & 12.54 & 87.18 & n.a. & n.a. & n.a. & 99.72 \\
\hline BF-2029 & 3 & 0.05 & n.a. & 0.11 & n.a. & 12.07 & 87.83 & n.a. & n.a. & 0.14 & 100.20 \\
\hline K-027-12 & 3 & n.a. & n.a. & n.a. & n.a. & 11.85 & 87.63 & n.a. & n.a. & n.a. & 99.48 \\
\hline 9015 & 4 & 0.41 & n.a. & n.a. & n.a. & 89.27 & 7.15 & 3.16 & n.a. & n.a. & 99.99 \\
\hline $107-62.8$ & & $<0.01$ & n.a. & 1.35 & n.a. & 8.73 & 89.50 & n.a. & n.a. & n.a. & 99.57 \\
\hline \multicolumn{12}{|c|}{ Formulae coefficients (calculated for $\Sigma$ Metals $=1$ ) } \\
\hline 090 & 1 & 0.025 & & 0.001 & 0.000 & 0.790 & 0.153 & 0.000 & 0.025 & 0.005 & \\
\hline $9014-23 a$ & 1 & 0.005 & 0.001 & 0.024 & & 0.742 & 0.197 & 0.013 & 0.009 & 0.010 & \\
\hline AK-707-1 & 1 & 0.002 & & & 0.005 & 0.846 & 0.125 & & & 0.022 & \\
\hline 700 & 2 & 0.000 & & 0.000 & 0.000 & 0.755 & 0.225 & 0.019 & 0.000 & 0.000 & \\
\hline 700 & 2 & 0.000 & & 0.000 & 0.000 & 0.709 & 0.263 & 0.028 & 0.000 & 0.000 & \\
\hline $711-8-23$ & 2 & 0.000 & & 0.000 & & 0.687 & 0.309 & 0.004 & 0.000 & & \\
\hline $711-8-23^{\prime}$ & 2 & 0.000 & & 0.000 & & 0.481 & 0.515 & 0.004 & 0.000 & & \\
\hline $711-2-1^{\prime}$ & 2 & 0.000 & & 0.000 & & 0.684 & 0.295 & 0.021 & 0.000 & & \\
\hline 711-2-1 & 2 & 0.000 & & 0.000 & & 0.534 & 0.458 & 0.008 & 0.000 & & \\
\hline AK-711A-1 & 2 & 0.003 & & & & 0.523 & 0.428 & & & 0.046 & \\
\hline 700 & 2 & 0.001 & & 0.001 & 0.000 & 0.560 & 0.429 & 0.009 & 0.000 & 0.000 & \\
\hline 284 & 2 & 0.000 & 0.000 & 0.000 & & 0.504 & 0.488 & 0.006 & 0.002 & 0.000 & \\
\hline 284 & 2 & 0.001 & 0.000 & 0.000 & & 0.374 & 0.621 & 0.002 & 0.002 & 0.000 & \\
\hline K13C-29/1 & 3 & & & & & 0.338 & 0.662 & & & & \\
\hline K-505.7 & 3 & & & 0.001 & & 0.212 & 0.787 & & & & \\
\hline K027-12/1 & 3 & & & & & 0.208 & 0.792 & & & & \\
\hline BF-2029 & 3 & 0.002 & & 0.003 & & 0.200 & 0.796 & & & 0.004 & \\
\hline K-027-12 & 3 & & & & & 0.198 & 0.802 & & & & \\
\hline $9015-14-1 a$ & 4 & 0.008 & & & & 0.922 & 0.040 & 0.029 & & & \\
\hline $107-62.8$ & & 0.000 & & 0.038 & & 0.145 & 0.817 & & & & \\
\hline
\end{tabular}

Notes: n.a. $=$ not analyzed; $\mathrm{R}=$ rim, and $\mathrm{C}=$ center of one and the same grain. 

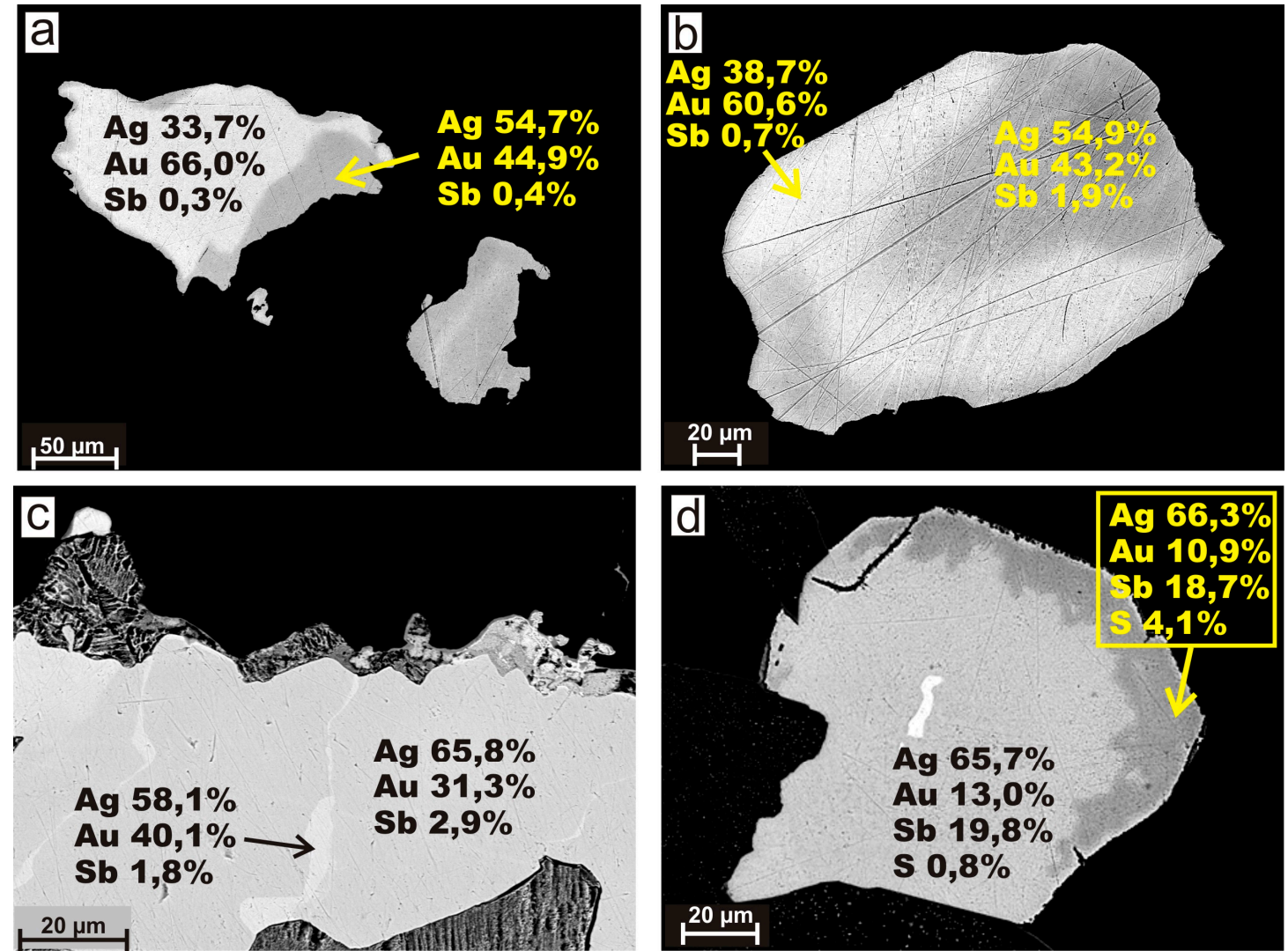

Figure 6. (a-c) Back scattered electron images of heterogenic electrum grains with electron microprobe data: $(\mathbf{a}, \mathbf{b})$ zonality in the electrum grains with the outer parts, enriched in $\mathrm{Ag}$ and $\mathrm{Sb}$; (c) microveinlets of electrum, enriched in gold, in electrum (the second type); (d) zonality in dyscrasite with an inclusion of electrum.

Table 4. Electron microprobe data in wt.\% for dyscrasite and uytenbogaardtiie.

\begin{tabular}{|c|c|c|c|c|c|c|c|c|c|c|c|}
\hline Mineral & Sample \# & $\mathrm{Fe}$ & $\mathrm{Cu}$ & $\mathrm{Zn}$ & $\mathrm{Pb}$ & Ag & $\mathrm{Au}$ & $\mathrm{Sb}$ & As & $\mathrm{S}$ & Total \\
\hline \multirow{7}{*}{ Dyscrasite } & 700 & $<0.01$ & 0.02 & 0.01 & $<0.01$ & 76.25 & 0.08 & 23.05 & 0.02 & $<0.01$ & 99.43 \\
\hline & 700 & 0.03 & 0.04 & 0.03 & $<0.01$ & 63.64 & 12.22 & 17.93 & 0.06 & $<0.01$ & 98.95 \\
\hline & $284-3$ & 0.01 & 0.02 & 0.01 & 0.07 & 69.84 & 10.46 & 19.00 & $<0.01$ & 0.01 & 99.41 \\
\hline & $136-1$ & 0.01 & $<0.01$ & 0.01 & 1.26 & 76.96 & 0.44 & 20.81 & $<0.01$ & 0.04 & 99.54 \\
\hline & 700 & $<0.01$ & $<0.01$ & n.a. & n.a. & 73.78 & 2.05 & 23.73 & n.a. & n.a. & 99.57 \\
\hline & 700 & $<0.01$ & n.a. & n.a. & n.a. & 73.82 & 3.04 & 23.48 & n.a. & n.a. & 100.33 \\
\hline & 700 & $<0.01$ & n.a. & n.a. & n.a. & 71.37 & 7.45 & 21.29 & n.a. & n.a. & 100.13 \\
\hline Uytenbogaardtite & AK-711-4 & 0.15 & n.a. & n.a. & n.a. & 59.86 & 26.88 & n.a. & $<0.01$ & 11.15 & 98.04 \\
\hline \multicolumn{12}{|c|}{ Formulae coefficients (calculated for $\mathrm{Sb}+\mathrm{As}+\mathrm{S}=1$ in dyscrasite, $\mathrm{S}=2$ in uytenbogaardtite) } \\
\hline \multirow{7}{*}{ Dyscrasite } & 700 & 0.000 & 0.001 & 0.000 & 0.000 & 3.728 & 0.002 & 0.999 & 0.001 & 0.000 & \\
\hline & 700 & 0.004 & 0.004 & 0.003 & 0.000 & 3.985 & 0.419 & 0.994 & 0.005 & 0.000 & \\
\hline & $284-3$ & 0.001 & 0.002 & 0.001 & 0.002 & 4.144 & 0.340 & 0.999 & 0.000 & 0.001 & \\
\hline & $136-1$ & 0.001 & 0.000 & 0.001 & 0.035 & 4.142 & 0.013 & 0.992 & 0.000 & 0.008 & \\
\hline & 700 & 0.000 & 0.000 & & & 3.509 & 0.053 & 1.000 & & & \\
\hline & 700 & 0.000 & & & & 3.549 & 0.080 & 1.000 & & & \\
\hline & 700 & 0.000 & & & & 3.784 & 0.216 & 1.000 & & & \\
\hline Uytenbogaardtite & AK-711-4 & 0.016 & & & & 3.191 & 0.785 & & 0.000 & 2.000 & \\
\hline
\end{tabular}

Note: n.a. = not analyzed.

Geochemical association of metals $\mathrm{Au}-\mathrm{As}-\mathrm{Ag}(\mathrm{Sb}-\mathrm{Cu}-\mathrm{Pb}-\mathrm{Zn}-\mathrm{B}-\mathrm{W})$ reflects complicated character of the mineralization. The deposit is rich in silver, and $\mathrm{Au} / \mathrm{Ag}$ ratio is less than 0.2 . 
Fluid inclusions in diopside from diopside-zoisite-carbonate matasomatic rock have high temperatures of homogenization $341-351^{\circ} \mathrm{C}$ and low salinity $1.1 \mathrm{wt} . \% \mathrm{NaCl}$-equivalent [19] (Table 5). Temperature of homogenization of fluid inclusions in quartz from quartz metasomatite with gold-arsenopyrite mineralization is lower, $120-160{ }^{\circ} \mathrm{C}$, the fluid has $\mathrm{H}_{2} \mathrm{O}-\mathrm{CO}_{2}$ composition with minor $\mathrm{CH}_{4}$, the salinity is high 13.4-13.5 wt.\% NaCl-equivalent, the main cations are $\mathrm{Na}, \mathrm{Ca}$, and $\mathrm{Mg}$ [19].

Mineralization in the Oleninsloe formed in the Neoarchean between $2.83 \mathrm{Ga}$ (the age of quartz porphyry dykes [20]) and $2.45 \mathrm{Ga}$ (the age of the pegmatite veins, cutting the mineralized rocks [21]).

Table 5. Microthermometric data for individual fluid inclusions in rock-forming minerals from gold deposits in the Kola region.

\begin{tabular}{|c|c|c|c|c|c|}
\hline $\begin{array}{c}\text { Gold } \\
\text { Deposit/Occurrence }\end{array}$ & Host Mineral & $\begin{array}{c}\text { Temperature of } \\
\text { Homogenization, }{ }^{\circ} \mathrm{C}\end{array}$ & $\begin{array}{c}\text { Fluid } \\
\text { Composition, } \\
\text { mole/kg }\end{array}$ & $\begin{array}{c}\text { Salinity, wt.\% } \\
\text { NaCl-equivalent; } \\
\text { Salt Composition }\end{array}$ & Pressure, Bar \\
\hline \multirow[b]{2}{*}{ Oleninskoe [19] } & Diopside & $341-351$ & No data & 1.1 & No data \\
\hline & $\begin{array}{l}\text { Quartz with gold } \\
\text { mineralization }\end{array}$ & $120-160$ & $\mathrm{H}_{2} \mathrm{O}-\mathrm{CO}_{2}-\mathrm{CH}_{4}$ & $\begin{array}{c}13.4-13.5 \\
\mathrm{Na}, \mathrm{Ca}, \mathrm{Mg}\end{array}$ & No data \\
\hline Nyal'm (this study) & Quartz from veinlets & $251-334$ & $\begin{array}{c}\mathrm{H}_{2} \mathrm{O}-\mathrm{CO}_{2}-\mathrm{CH}_{4} \\
\mathrm{CO}_{2} 4.3-5.8 \\
\mathrm{CH}_{4} 0.5-0.7\end{array}$ & $2.5-5.6$ & $1130-3290$ \\
\hline \multirow[b]{2}{*}{ Porojarvi [22] } & $\begin{array}{l}\text { Quartz from } \\
\text { metasomatic quartzite }\end{array}$ & $242-336$ & $\begin{array}{c}\mathrm{H}_{2} \mathrm{O}-\mathrm{CO}_{2}-\mathrm{CH}_{4} \\
\mathrm{CO}_{2} 4.3-7.8 \\
\mathrm{CH}_{4} 0.6-0.9\end{array}$ & $\begin{array}{c}0.4-3.8 \\
\mathrm{Na}, \mathrm{Ca}, \mathrm{Mg}, \mathrm{K} \\
(\mathrm{Au} 4.6 \mathrm{ppm})\end{array}$ & $1200-2580$ \\
\hline & $\begin{array}{c}\text { Quartz from } \\
\text { quartz-albite- carbonate } \\
\text { metasomatite }\end{array}$ & $342-370$ & $\begin{array}{c}\mathrm{H}_{2} \mathrm{O}-\mathrm{CO}_{2}-\mathrm{CH}_{4} \\
\mathrm{CO}_{2} 5.3-8.8 \\
\mathrm{CH}_{4} 0.6-1.1\end{array}$ & $\begin{array}{c}0.6-1.0 \\
\mathrm{Na}, \mathrm{Ca}, \mathrm{Mg}, \mathrm{K} \\
(\mathrm{Au} 202 \mathrm{ppm})\end{array}$ & $2130-4550$ \\
\hline \multirow{4}{*}{ Mayskoe [23] } & Quartz from propylite & $280-320$ & $\mathrm{H}_{2} \mathrm{O}-\mathrm{NaCl}$ & $25-30$ & No data \\
\hline & Vein quartz & $320-350$ & No data & $1.7-7.7$ & No data \\
\hline & $\begin{array}{c}\text { Granulated quartz from } \\
\text { the ore shoots }\end{array}$ & $190-270$ & $\begin{array}{c}\mathrm{CO}_{2}-\mathrm{CH}_{4} \\
\mathrm{CH}_{4} 16-70 \%\end{array}$ & $22-26 \mathrm{Ca}$ & $940-500$ \\
\hline & $\begin{array}{l}\text { Quartz with gold in } \\
\text { inclusions }\end{array}$ & 140-198 & No data & $22-28 \mathrm{Ca}$ & No data \\
\hline
\end{tabular}

Small gold deposit Nyal'm (\#2 in Figure 1) is located $18 \mathrm{~km} \mathrm{SE}$ from the Oleninskoe, at the SE thinning of the same stratum of the Oleny Ridge amphibolite. Geological setting, mineralogical, petrographical, and geochemical characteristics of the Nyal'm deposit differ significantly from those of the Oleninskoe (Table 2).

Mineralization at the Nyal'm is spatially confined to a stockwork of quartz-carbonate veinlets at tectonized contacts of a minor intrusion of diorite porphyry, hosted by a amphibolite and carbonaceous schist (Figure 7). The intrusion is differentiated: rock composition varies from gabbrodiorite in the center to granodiorite porphyry in the marginal part.

A network system of mineralized quartz-carbonate veins and veinlets forms two linear stockworks up to $15-\mathrm{m}$ thick, orientated parallel to elongation of the intrusion. Concentration of veinlets in the stockworks is normally less than 10 vol.\%, but in two vein zones (3.0- and 0.8 -m thick) it increases to 80 vol.\%.

Content of ore minerals is less than $3 \%$, and pyrrhotite, ilmenite, and rutile prevail. Some pyrrhotite grains contain intergrowths of chalcopyrite, pyrite, flame-like pentlandite, and sporadically, sphalerite. Arsenopyrite and cobaltite were noted less frequently.

Visible native gold concentrates mainly in the central parts of quartz-carbonate veinlets. Gold grains are $<0.7 \mathrm{~mm}$ in size, idiomorphic, isolated in quartz, intergrowths of gold with sulfides were not found. The gold fineness is high, from 870 to 920 [24]. The weighted average is $1.2 \mathrm{ppm} \mathrm{Au}$ in the stockworks, and 11.6 and $12.8 \mathrm{ppm}$ in two "vein zones". Inferred resources of the deposit are estimated at $7.5 \mathrm{t} \mathrm{Au}$ (down to $100 \mathrm{~m}$ depth) [16]. 

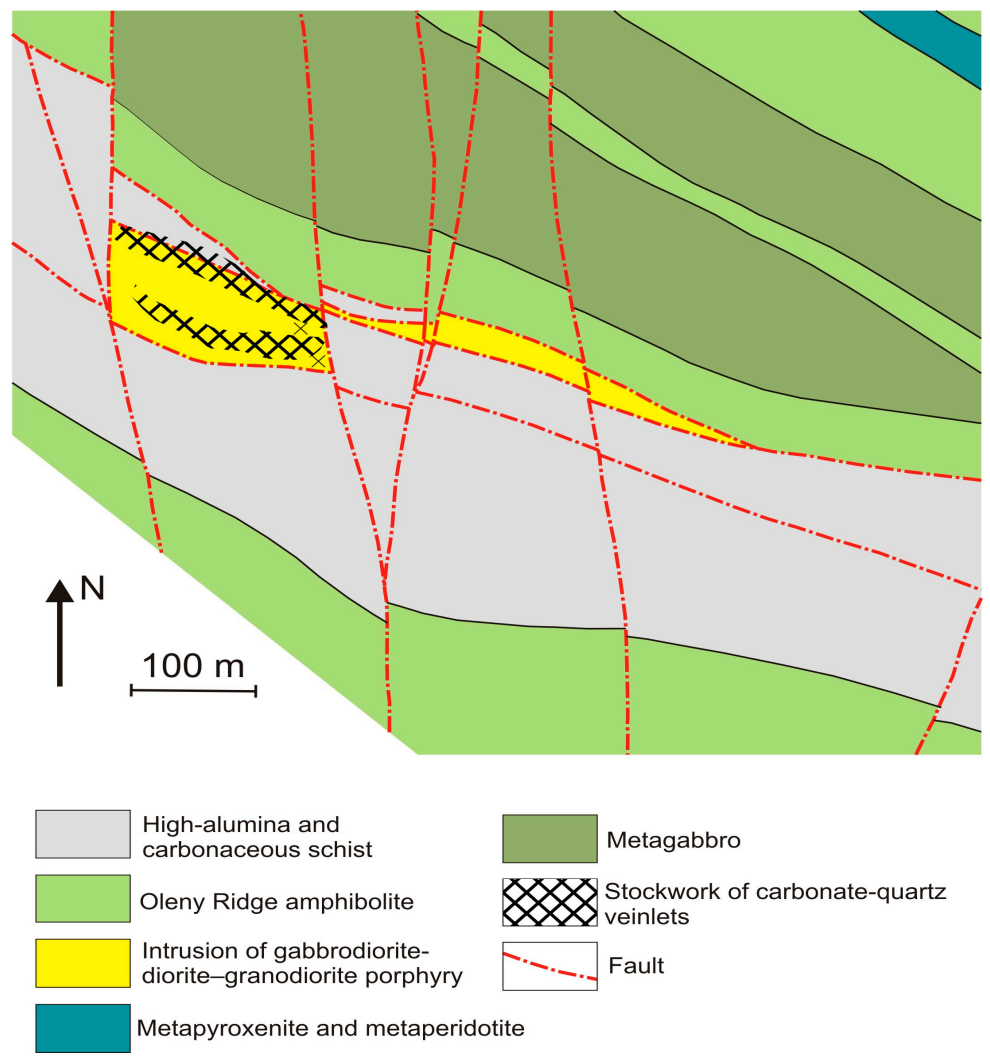

Figure 7. Schematic geological map of the Nyal'm-1 gold deposit area.

Temperature of homogenization of the primary fluid inclusions in quartz varies from 251 to 334 ${ }^{\circ} \mathrm{C}$ (Table 5). Composition of the fluid is $\mathrm{H}_{2} \mathrm{O}-\mathrm{CO}_{2}$, with minor $\mathrm{CH}_{4}$. Salinity is low, 2.5-5.6 wt.\% NaCl -equivalent; $\mathrm{Na}, \mathrm{Mg}$, and Fe chlorides prevail. Estimated fluid pressure is 1.13-3.29 kbar.

The Mo-Cu porphyry deposit Pellapahk, mentioned in References $[9,10]$ as a gold-bearing one, is located in the Kolmozero-Voron'ya belt, 2-km west of Oleninskoe. Mineralized stockwork in the Pellapahk deposit is hosted by altered granodiorite-granite porphyry, which underwent acidic leaching and turned into muscovite-kyanite, muscovite-andalusite, and muscovite metasomatic quartzite [25]. The mineralized stockwork occupies area $1500 \times 350-600 \mathrm{~m}$. Content of sulfide mineralization in the stockwork is $1-2$ vol. $\%$, sporadically up to 10 vol. $\%$. Sulfide concentrate from the deposit contains $2.5 \mathrm{ppm} \mathrm{Au} \mathrm{[16]} \mathrm{(the} \mathrm{calculated} \mathrm{gold} \mathrm{content} \mathrm{in} \mathrm{the} \mathrm{rock} \mathrm{is} 0.08 \mathrm{ppm}$ ), and $200 \mathrm{ppm}$ $\mathrm{Ag}$, hypothetic resources ( $\mathrm{P}_{3}$ according to the Russian classification of resources) of the deposit are estimated at $10 \mathrm{t} \mathrm{Au} \mathrm{[16].}$

According to information obtained during the last decade [25], the inferred ore resources of the deposit are estimated at 152 million tons, with an average Mo content of 0.028 mas. $\%$, and $\mathrm{Cu} 0.154 \%$. The resources of molybdenum and its grades are much lower than the average for the porphyry deposits, and this information significantly decreases interest in exploration of the Pellapahk deposit as a source of $\mathrm{Mo}, \mathrm{Cu}$, and, consequently, $\mathrm{Au}$.

\subsection{Gold Deposits and Occurrences in the Strel'na Greenstone Belt}

The Strel'na greenstone belt is the easternmost structure of the Neoarchean belt system at the southern flank of the Imandra-Varzuga greenschist belt (Figure 1). It is a part of the Srel'na terrane, made mainly of the Neoarchean rocks intensely reworked in the Paleoproterozoic. The boundary between the Strel'na and Imandra-Varzuga belts is of tectonic character-an overthrust of the Neoarchean rocks (the Strel'na greenstone belt) over the Paleoproterozic metavolcanics (the Imandra Varzuga belt) (Figure 2). 
The Strel'na belt hosts small gold deposit Sergozero, gold occurrence Vorgovy, and a number of points of gold mineralization (Figures 1 and 2).

The Sergozero deposit (\#3 in Figure 1) is located 1.5-2-km south from the mentioned regional overthrust fault zone, at a second order shear zone, parallel to the main fault. Geological structure of the deposit is defined by the strata of amphibolite and amphibole schist with a composition corresponding to komatiite, komatiitic, and tholeiitic basalts, within a series of fine-grained muscovite-biotite and biotite schists (Figure 8). The rocks are greenschist-lower amphibolite metamorphosed (Table 6). Supracrustal rocks are intruded with dykes and minor intrusions of diorite porphyry (1875 $\pm 2 \mathrm{Ma}$, $\mathrm{U}-\mathrm{Pb}$, zircon [26]) and granite ( 1.83 Ga?).

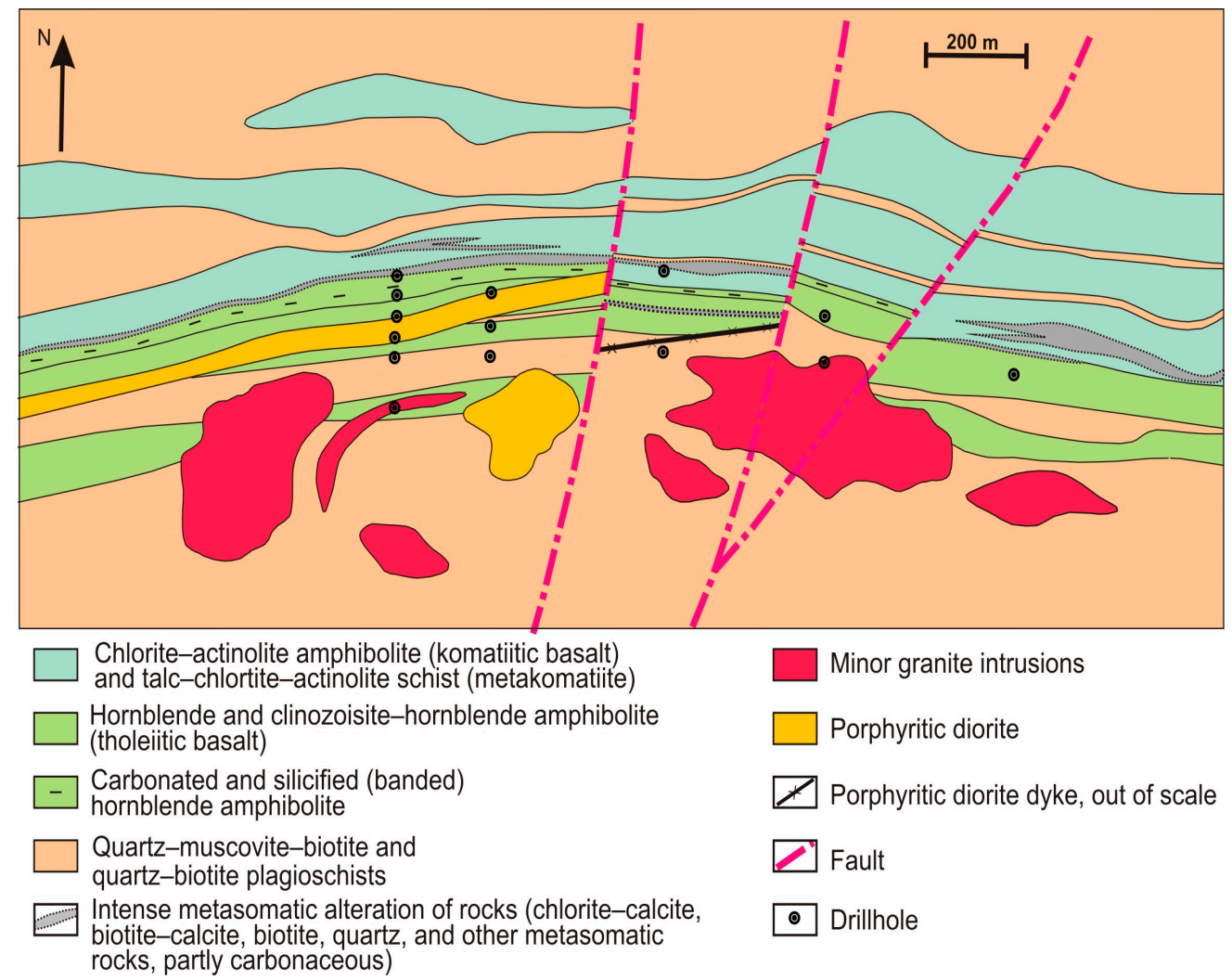

Figure 8. Schematic geological map of the Sergozero gold deposit.

All volcanic-sedimentary rocks in the deposit and diorite porphyry in the dykes are schistose, foliated, cut by hydrothermal veinlets, in some parts brecciated and altered. The prevalent alteration processes are chloritization (up to $60 \mathrm{vol} . \%$ of newly formed chlorite), biotitization, graphitization, silicification, and carbonatization. The total thickness of the zone of alteration varies from 60 to $120 \mathrm{~m}$. This tract comprises the entire sequence of the hornblende amphibolite, the upper part of the chlorite-actinolite rocks, and the porphyry diorite dykes, which cut the amphibolites.

All rocks in the deposit, except granite, contain sulfide mineralization. The list of ore minerals includes pyrrhotite, arsenopyrite, pyrite, chalcopyrite, gersdorfite-cobaltite, sphalerite, pentlandite, galena, molybdenite, scheelite, native gold, and, less frequently, ulmannite and hessite. The mineralization is disseminated, veinlet-disseminated, nested; content of sulfides reaches $10 \mathrm{vol} . \%$.

The main mineralized zone follows the contact between hornblende and actinolite-chlorite amphibolites. High gold grades (up to $5.7 \mathrm{ppm}$ ) relate to the biotite-calcite metasomatic rocks after hornblende amphibolite, chlorite-actinolite amphibolite, and diorite porphyry (Figure 9). 
Table 6. General characteristics of the gold deposits in the Strel'na greenstone belt.

\begin{tabular}{|c|c|c|c|}
\hline \multicolumn{2}{|c|}{ Deposit/occurrence } & Sergozero & Vorgovy \\
\hline \multicolumn{2}{|c|}{ Tectonic structure } & $\begin{array}{l}\text { Second-order faults, accompanying the } \\
\text { regional overthrust of the Neoarchean Strel'na } \\
\text { belt onto Paleoproterozoic rocks of the } \\
\text { Imandra-Varzuga belt }\end{array}$ & $\begin{array}{l}\text { Regional overthrust of the Neoarchean } \\
\text { Strel'na belt onto Paleoproterozoic rocks } \\
\text { of the Imandra-Varzuga belt }\end{array}$ \\
\hline \multicolumn{2}{|c|}{ Host rocks } & $\begin{array}{l}\text { Hornblendite (tholeiitic basalt), } \\
\text { chlorite-actinolite amphibolite (komatiite, } \\
\text { komatiitic basalt), diorite porphyry dykes }\end{array}$ & $\begin{array}{l}\text { Biotite gneisses and schists with interbeds } \\
\text { of mafic-ultramafic metavolcanics }\end{array}$ \\
\hline \multicolumn{2}{|c|}{ Regional metamorphism } & \multicolumn{2}{|c|}{ Paleoproterozoic 1.8-1.9 Ga, greenschist-lower amphibolite } \\
\hline \multirow{3}{*}{$\begin{array}{l}\text { Alteration (assemblages of } \\
\text { new formed minerals) }\end{array}$} & -pre-ore & Chlorite & $\begin{array}{l}\text { Quartz-chlorite-sericite and } \\
\text { quartz-sericite }\end{array}$ \\
\hline & -gold-related & $\begin{array}{c}\mathrm{K}-\mathrm{CO}_{2}-\mathrm{Si} \\
\text { Quartz-calcite-biotite }\end{array}$ & $\begin{array}{c}\mathrm{Si}-\mathrm{CO}_{2}-(\mathrm{K}) \\
\text { Stockwork of quartz-carbonate and } \\
\text { quartz veinlets }\end{array}$ \\
\hline & -post-ore & Quartz-calcite & Not defined \\
\hline \multicolumn{2}{|c|}{ Mineralized bodies } & $\begin{array}{l}\text { Lenses up to } 14-\mathrm{m} \text { thick and up to } 150-\mathrm{m} \text { long. } \\
\text { The best section is } 5.3 \mathrm{ppm} \text { Au for } 3.3 \mathrm{~m} \text { in a } \\
\text { drillhole by the Central Kola Expedition (CKE); } \\
\text { average gold grade } 3.1 \mathrm{ppm}\end{array}$ & $\begin{array}{l}\text { Not contoured, the best section is } 4 \mathrm{ppm} \\
\text { for } 1 \mathrm{~m} \text { in a trench by the CKE }\end{array}$ \\
\hline \multicolumn{2}{|c|}{ Texture of mineralization, sulfide content (vol.\%) } & Disseminated, 1-3 & Nested, nested-disseminated, up to $0.1-5$ \\
\hline \multicolumn{2}{|c|}{ Main ore minerals } & Arsenopyrite, pyrrhotite, gersdorfite & Arsenopyrite, pyrrhotite \\
\hline \multicolumn{2}{|c|}{ Minor ore minerals } & $\begin{array}{l}\text { Ilmenite, chalcopyrite, pyrite, pentlandite, } \\
\text { cobaltite, sphalerite, galena, sheelite }\end{array}$ & $\begin{array}{c}\text { Pyrite, sphalerite, galena, chalcopyrite, } \\
\text { pentlandite, cobaltite, marcasite, } \\
\text { mackinawite }\end{array}$ \\
\hline \multicolumn{2}{|c|}{ Geochemical association, ratio $\mathrm{Au} / \mathrm{Ag}$} & $\begin{array}{c}\mathrm{Au}, \mathrm{As}, \mathrm{Ni} \\
\mathrm{Au} / \mathrm{Ag}=2-6\end{array}$ & $\begin{array}{c}\mathrm{Au}, \mathrm{As} \\
\mathrm{Au} / \mathrm{Ag}>1\end{array}$ \\
\hline \multicolumn{2}{|c|}{ Age of mineralized rocks } & $\begin{array}{l}\text { Paleoproterozoic - later than } 1875 \pm 2 \mathrm{Ga} \text { (age } \\
\text { of the diorite porphyry dyke); Rb-Sr age of } \\
\text { quartz-calcite-biotite gold-related mineral } \\
\text { association } 1739 \pm 86 \mathrm{Ma}\end{array}$ & Paleoproterozoic (?) \\
\hline \multicolumn{2}{|c|}{ Gold characteristics, fineness in \%o } & $\begin{array}{l}\text { Fine-grained }(<0.1 \mathrm{~mm}) \text { gold with fineness } \\
760-960 \text { in association with arsenopyrite and } \\
\text { gersdorfite }\end{array}$ & $\begin{array}{l}\text { Spongy, porous, lumpy or flattened grains } \\
0.1-0.25 \mathrm{~mm} \text {, the gold fineness is } 890-940 \text {. }\end{array}$ \\
\hline
\end{tabular}
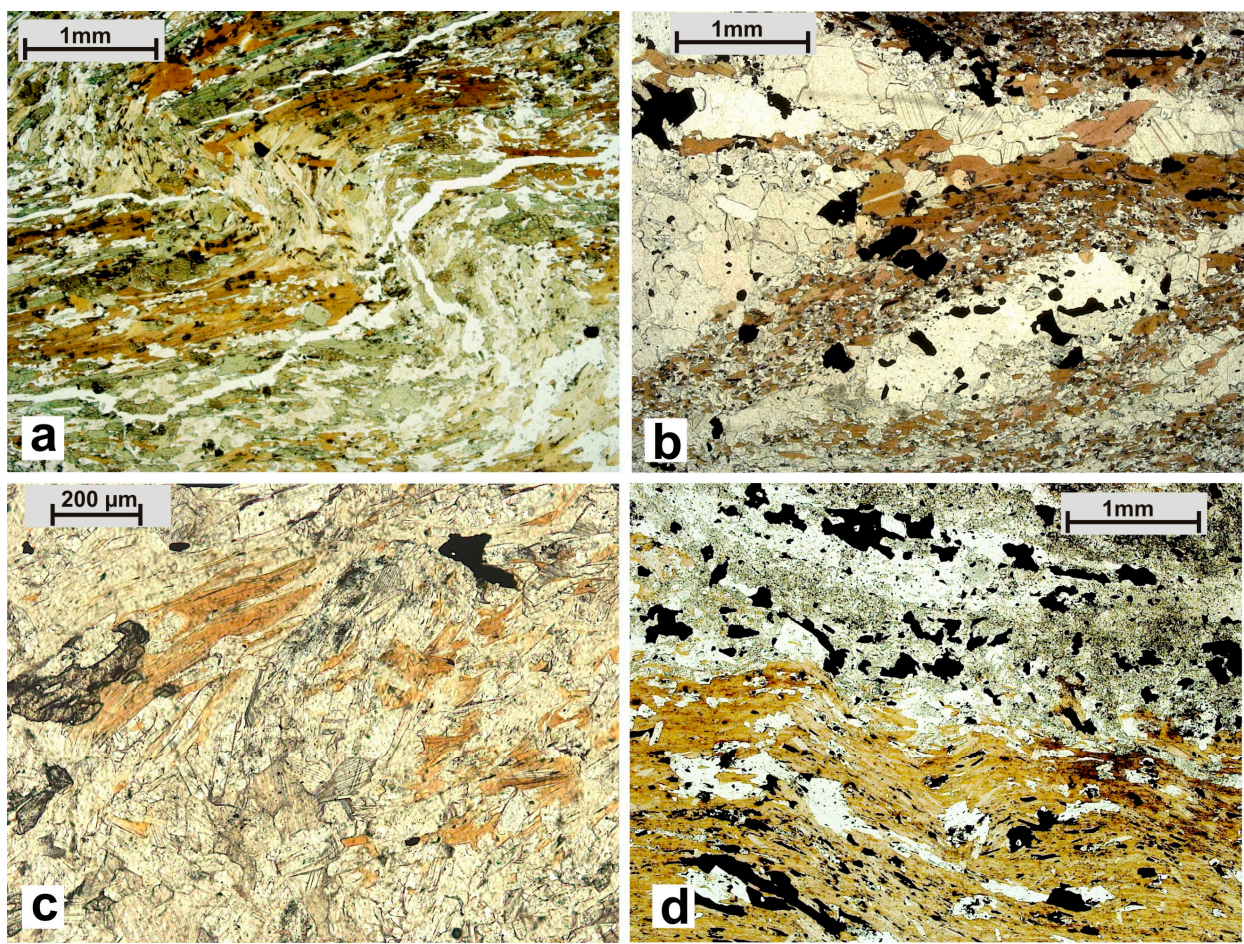

Figure 9. Altered rocks from the Sergozerskoe gold occurrence, thin sections photos, transparent light, one polarizer. (a) Biotitizated folded hornblende amphibolite, (b-d) calcite-biotite metasomatite: (b) after hornblende amphibolite, (c) after actinolite-chlorite amphibolite, (d) after diorite porphyry. 
Native gold associates with arsenopyrite and gersdorfite. Gold grains more often are located at the boundary between sulfides and vein minerals (Figure 10). The prevalent gold grain dimension is 10-40 $\mu \mathrm{m}$, maximum $0.1 \mathrm{~mm}$, the grains are idiomorphic or lumpy. The fineness is high (957\% on the average for 16 samples), medium (792\%o for 5 samples), and rarely low (672\%).

The best section is 2.13 ppm for $13.7 \mathrm{~m}$, including $5.3 \mathrm{ppm}$ for $3.3 \mathrm{~m}$ in drillhole \#SRG-14. Inferred resources of the deposit are estimated at $13 \mathrm{t} \mathrm{Au}$.

Mineralization in the Sergozero deposit formed in the Paleoproterozoic: age of diorite porphyry dyke, which is the youngest gold-bearing rock, is $1875 \pm 2 \mathrm{Ma}$ (U-Pb, zircon) [26]. Age of alteration processes, estimated with the $\mathrm{Rb}-\mathrm{Sr}$ method for calcite-biotite metasomatic rocks is $1739 \pm 86 \mathrm{Ma}$ [26]. Thus, gold mineralization was superimposed on the Neoarchean amphibolites during the Paleoproterozoic tectonic events.
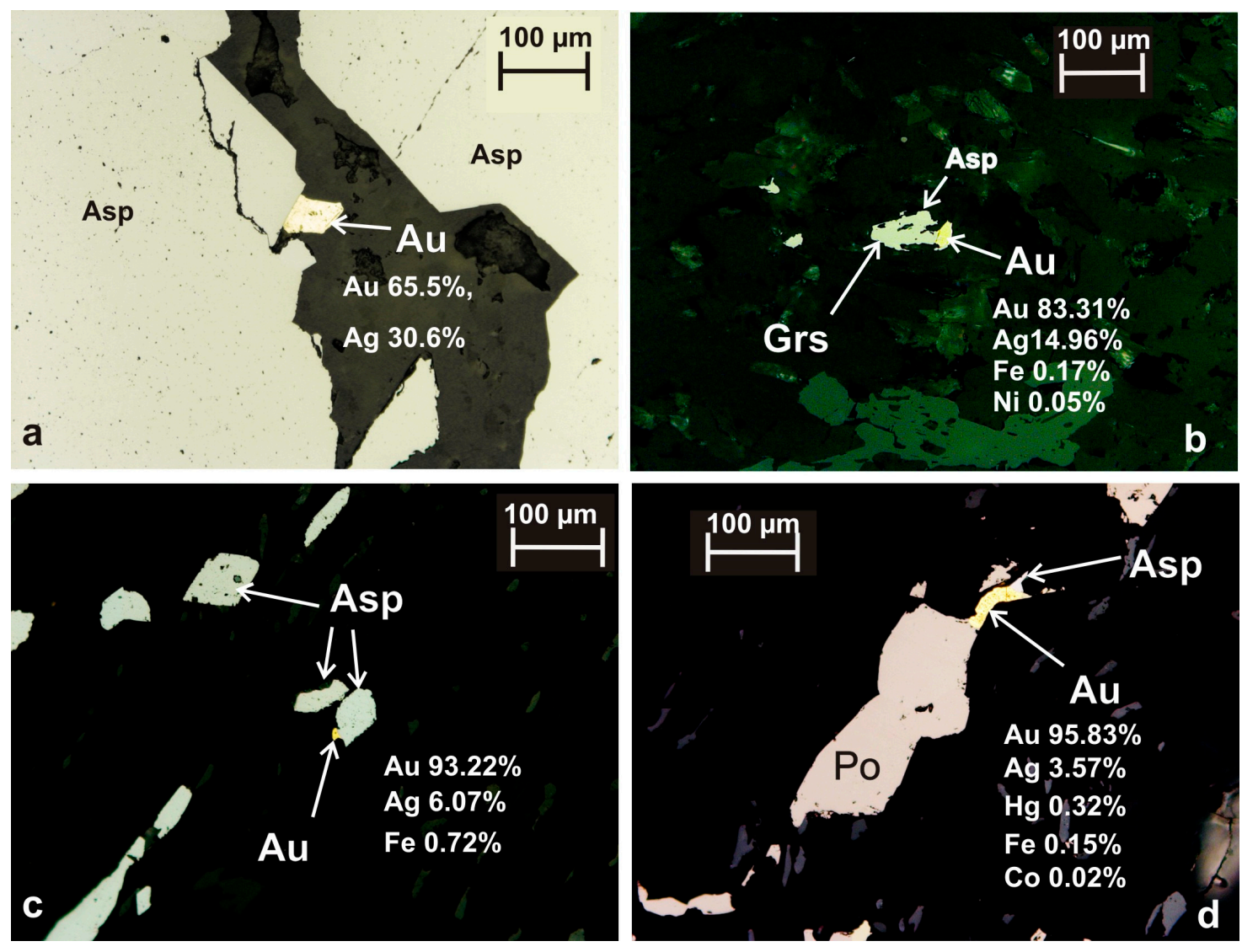

Figure 10. Gold with arsenopyrite and pyrrhotite, polished section photos, reflected light, one polarizer. (a) electrum and quarts in a fracture in arsenopyrite, (b) gold at the boundary of gersdorfite and silicate minerals, (c) gold at the boundary of arsenopyrite and silicate minerals, (d) gold with pyrrhotite and arsenopyrite.

The Vorgovy occurrence (\#4 in Figure 1) is located 2-km north from the Sergozerskoe, at the zone of tectonic contact of the Neoarchean and Paleoproterozoic rocks (Figure 11): The Strel'na belt sequence of biotite schists and gneisses with interbeds of mafic and ultramafic metavolcanics is upthrown over the metavolcanics of the Imandra Varzuga belt at an angle of $60^{\circ}$. The rocks near the reverse fault zone are intensely deformed (folds with a limb span from a few centimeters to tens of meters), and metasomatically altered-transformed to quartz-sericite-chlorite and quartz-sericite schists, partly graphitized. Thickness of the zone of foliation and alteration is approximately $150 \mathrm{~m}$ (Figure 11). 
Mineralization in the Vorgovy occurrence relates to a stockwork system of quartz and carbonate-quartz veins and veinlets hosted by chlorite-sericite-quartz metasomatic rocks after biotite gneiss. The stockwork zone is 100-150 m thick, extends for more than $1500 \mathrm{~m}$, and dips southwest at an angle of $60^{\circ}$. Productive sulfide mineralization in veinlets includes arsenopyrite, pyrite, sphalerite, galena, and native gold. Despite the fact that superimposed veinlets and sulfide mineralization occur within a vertical interval of more than $100 \mathrm{~m}$, the increased gold concentration up to $4 \mathrm{ppm}$, agreed with increase in arsenic content, have been found only in a 1-m interval immediately at the contact of sericite-chlorite-quartz schist and sericite quartzite.

Gold at the Vorgovy is spongy, porous, lumpy or flattened in shape. Predominant dimensions of gold grains are $0.1-0.25 \mathrm{~mm}$. Fineness of gold is $890-940 \%$; $\mathrm{Ag}, \mathrm{Cu}$, and Fe occur as impurities in gold [24].

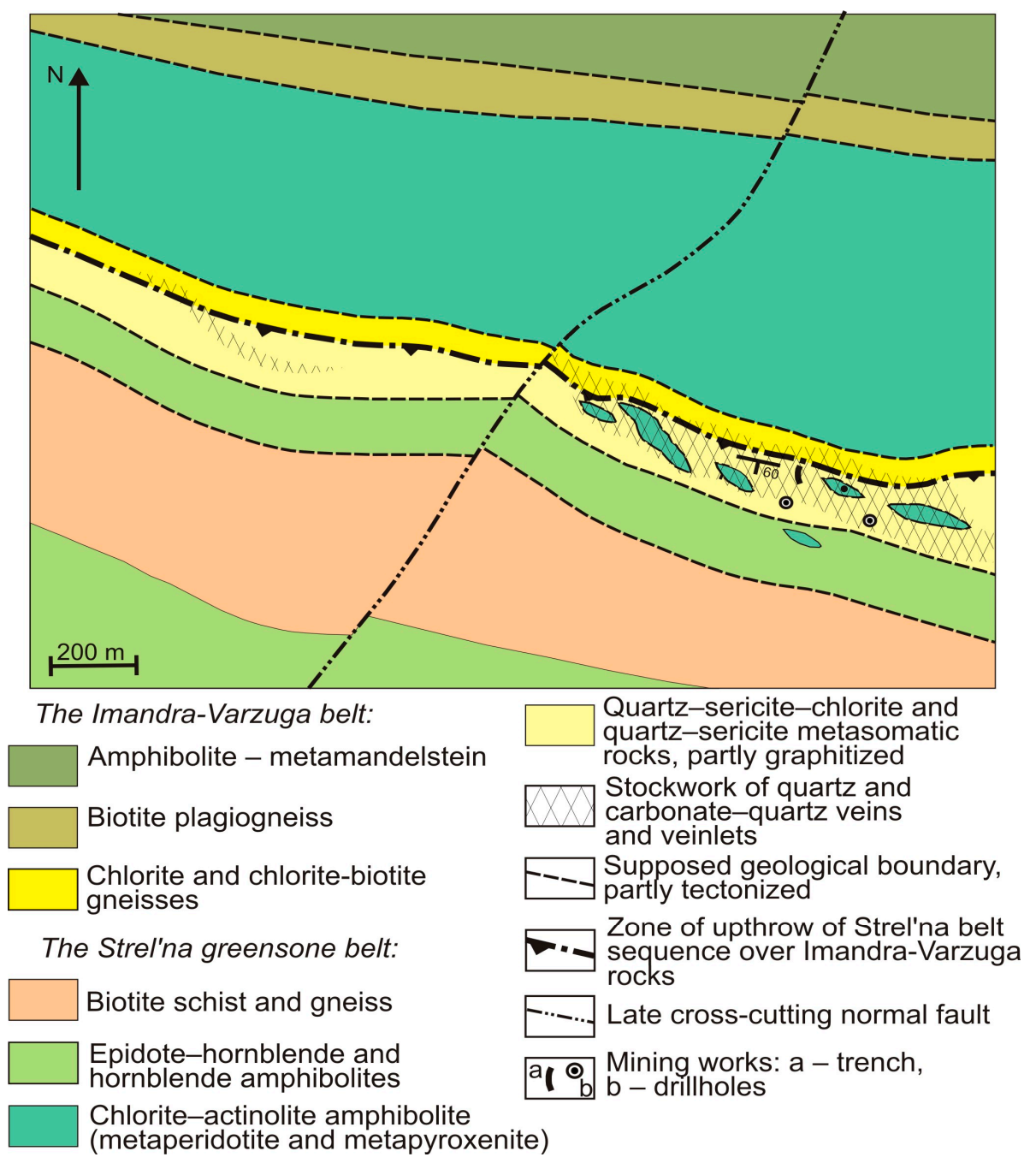

Figure 11. Schematic geological map of the Vorgovy gold occurrence. 


\subsection{Gold Occurrences in the Tiksheozero Greenstone Belt}

The Tiksheozero belt is a part of greenstone belt system at the southwestern flank of the Belomorian mobile belt (Figure 1). The rocks in the belt were amphibolite metamorphosed twice-in the Neoarchean ( $\mathrm{T} \sim 665-700{ }^{\circ} \mathrm{C}, \mathrm{P}=7-11 \mathrm{kbar}$ ), and in the Paleoproterozoic ( $\left.\mathrm{T} \sim 575-630{ }^{\circ} \mathrm{C}, \mathrm{P}=5.0-6.5 \mathrm{kbar}\right)$ [27].

The Kichany occurrence (\#7 in Figure 1) is located in the central part of the belt, in the Kichany synform (Figure 12) in a stratum of amphibolite (tholeiitic metabasalt) with interbeds of plagiogneiss-metatuffite. A series of thrusts at an angle of $30-40^{\circ}$ splits the stratum to thin slabs, in the outcrops the thrusts reveal in intense jointing and schistosity of rocks [28].

The thrusts control zones of intense rock alteration. One of these zones, 50-m thick, was traced in the amphibolite along the shore of the lake Verhnie Kichany for more than $2.5 \mathrm{~km}$ (Figure 12). The main alteration processes in the amphibolite are calcium metasomatism with formation of diopside-epidote-calcite-Ca-rich almandine, or diopside-scapolite-epidote ( \pm titanite) mineral assemblages, and silicification (quartz metasomatite with minor biotite) (Tables 7 and 8).

Arsenopyrite-pyrrhotite sulfide mineralization (with chalcopyrite, sphalerite, pyrite, marcasite, ilmenite, rutile, and native gold) was found in the zone of silicification at the boundary of garnet and feldspar amphibolites (Figure 13). Thickness of the mineralized zone is $1.2-1.5 \mathrm{~m}$, and the length is more than $30 \mathrm{~m}$. The weighted average gold content in the silicified amphibolite is $4.4 \mathrm{ppm}$ for $1.3 \mathrm{~m}$, including $0.3 \mathrm{~m}$ with $17.4 \mathrm{ppm} \mathrm{Au}$.

Table 7. General characteristics of gold occurrences in the Tiksheozero and Olenegorsk greenstone belts.

\begin{tabular}{|c|c|c|}
\hline Deposit/Occurrence & Kichany & Olenegorsk BIF Deposits [29-31] \\
\hline Greenstone belt & Tiksheozero, Kichany structure (AR) & Olenegorsk (AR) \\
\hline Tectonic structure & $\begin{array}{l}\text { A series of thrusts in the central part of the } \\
\text { Kichany synform }\end{array}$ & \\
\hline Host rocks & $\begin{array}{l}\text { Hornblendite and garnet amphibolite (tholeiitic } \\
\text { basalts), interlayered with biotite gneiss }\end{array}$ & Magnetite-sulfide quartzite \\
\hline Regional metamorphism & $\begin{array}{l}\text { 1) Neoarchean } 2.6-2.9 \mathrm{Ga} \text {, upper amphibolite } \\
\mathrm{T} \sim 665-700{ }^{\circ} \mathrm{C}, \mathrm{P}=7-11 \mathrm{kbar} ; \\
\text { 2) Paleoproterozoic } \sim 1.8 \mathrm{Ga} \text {, amphibolite } \mathrm{T} \sim \\
575-630^{\circ} \mathrm{C}, \mathrm{P}=5.0-6.5 \mathrm{kbar}\end{array}$ & Neoarchean $\sim 2750 \mathrm{Ga}$, amphibolite \\
\hline \multirow{3}{*}{$\begin{array}{l}\text { Alteration, assemblages } \\
\text { of new formed minerals }\end{array}$} & $\begin{array}{c}\text { Ca } \\
\text { Diopside-epidote-calcite-garnet, } \\
\text { diopside-scapolte }\end{array}$ & $\begin{array}{l}\mathrm{Ca}-\mathrm{Si} \\
\text { Amphibole-epidote-garnet-calcite-quartz; } \\
\text { diopside-magnetite }\end{array}$ \\
\hline & $\begin{array}{l}\text { Si-K } \\
\text { Quartz, quartz-biotite }\end{array}$ & $\begin{array}{c}\text { Ca-Si } \\
\text { Hydrothermal veins of quartz, calcite, } \\
\text { diopside-calcite, hornblende-almandine, } \\
\text { quartz-calcite-almandine composition }\end{array}$ \\
\hline & Not defined & Not defined \\
\hline Mineralized bodies & The best section $4.4 \mathrm{ppm}$ for $1.3 \mathrm{~m}$ in an outcrop & $\begin{array}{l}\text { Average gold grade } 1.36 \mathrm{ppm} \text { for } 18 \mathrm{~m} \text { in } \\
\text { magnetite-sulfide quartzite, maximum } 10.6 \mathrm{ppm}\end{array}$ \\
\hline $\begin{array}{l}\text { Texture of mineralization, sulfide content } \\
\text { (vol.\%) }\end{array}$ & Disseminated, $1-5$ & Disseminated, 1-5 \\
\hline Main ore minerals & Arsenopyrite, pyrrhotite, pyrite & Pyrrhotite, pyrite, chalcopyrite \\
\hline Minor ore minerals & $\begin{array}{l}\text { Chalcopyrite, marcasite, molybdenite, } \\
\text { sphalerite, rutile, ilmenite, gold }\end{array}$ & $\begin{array}{l}\text { Galena, sphalerite, molybdenite, electrum, sulfides } \\
\text { and tellurides of } \mathrm{Ag}, \mathrm{Bi} \text {, and } \mathrm{Au}\end{array}$ \\
\hline Geochemical association, ratio $\mathrm{Au} / \mathrm{Ag}$ & $\begin{array}{c}\mathrm{Au}-\mathrm{As} \\
\mathrm{Au} / \mathrm{Ag}=10\end{array}$ & $\begin{array}{c}\text { No data, } \\
\mathrm{Au} / \mathrm{Ag}=0.4\end{array}$ \\
\hline Age of mineralized rocks & $\begin{array}{l}\text { Paleoproterozoic (?)-1739 } \pm 15 \mathrm{Ma}(\mathrm{U}-\mathrm{Pb} \\
\text { titanite with inclusions of gold) }\end{array}$ & $\begin{array}{c}\text { Neoarchean } 2645-2675 \mathrm{Ma}(\mathrm{U}-\mathrm{Pb} \text {, zircon from } \\
\text { hydrothermal veins) }\end{array}$ \\
\hline Gold characteristics, fineness in \%o & $\begin{array}{c}\text { Fine }(<0.1 \mathrm{~mm}) \text { hexahedral and irregular gold } \\
\text { grains in association with arsenopyrite, } \\
\text { marcasite, inclusions in quartz and in silicate } \\
\text { minerals (oligoclase, titanite, hornblende), rare } \\
\text { in pyrrhotite and chalcopyrite. Gold fineness } \\
890-910 .\end{array}$ & $\begin{array}{l}\text { Gold grains from non-magnetic heavy concentrate } \\
\text { are of tabular, flaky, hooked, or of regular form, } \\
0.2-0.5 \mathrm{~mm} \text {. Gold fineness from } 490 \text { to } 940 \text {. }\end{array}$ \\
\hline
\end{tabular}




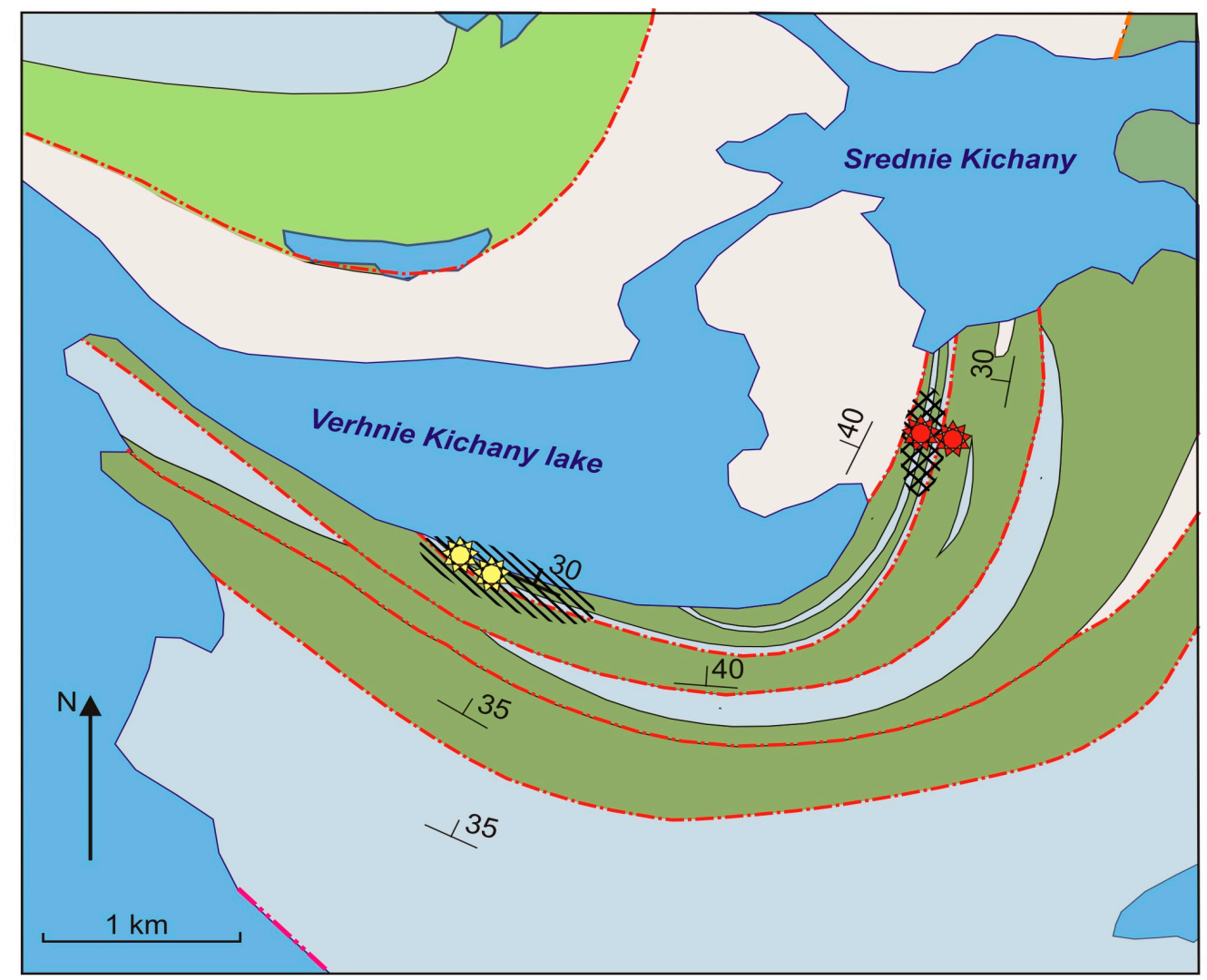

Tiksheozero belt:

Garnet amphibolite with interbeds and lenses of biotite gneiss

Feldspar amphibolite with interbeds of biotite gneiss

Leucocratic biotite and biotitegarnet gneiss with interbeds of amphibolite

Silicification and skarnification

Belomorian mobile belt:

Biotite granite-gneiss and biotite-muscovite gneiss

Scapolotization,

epidotization, silicification

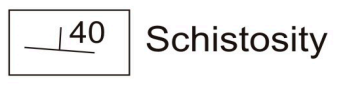

a : - :- Thrust (a) and steeply dipping fault (b)

Occurrences and points of gold mineralization (>0.5 ppm Au):

In quartz-diopside-scapolite metasomatite with pyrite and pyrrhotite

In quartz metasomatite with arsenopyrite and pyrrhotite

Figure 12. Schematic geological map of the Kichany gold occurrence. 

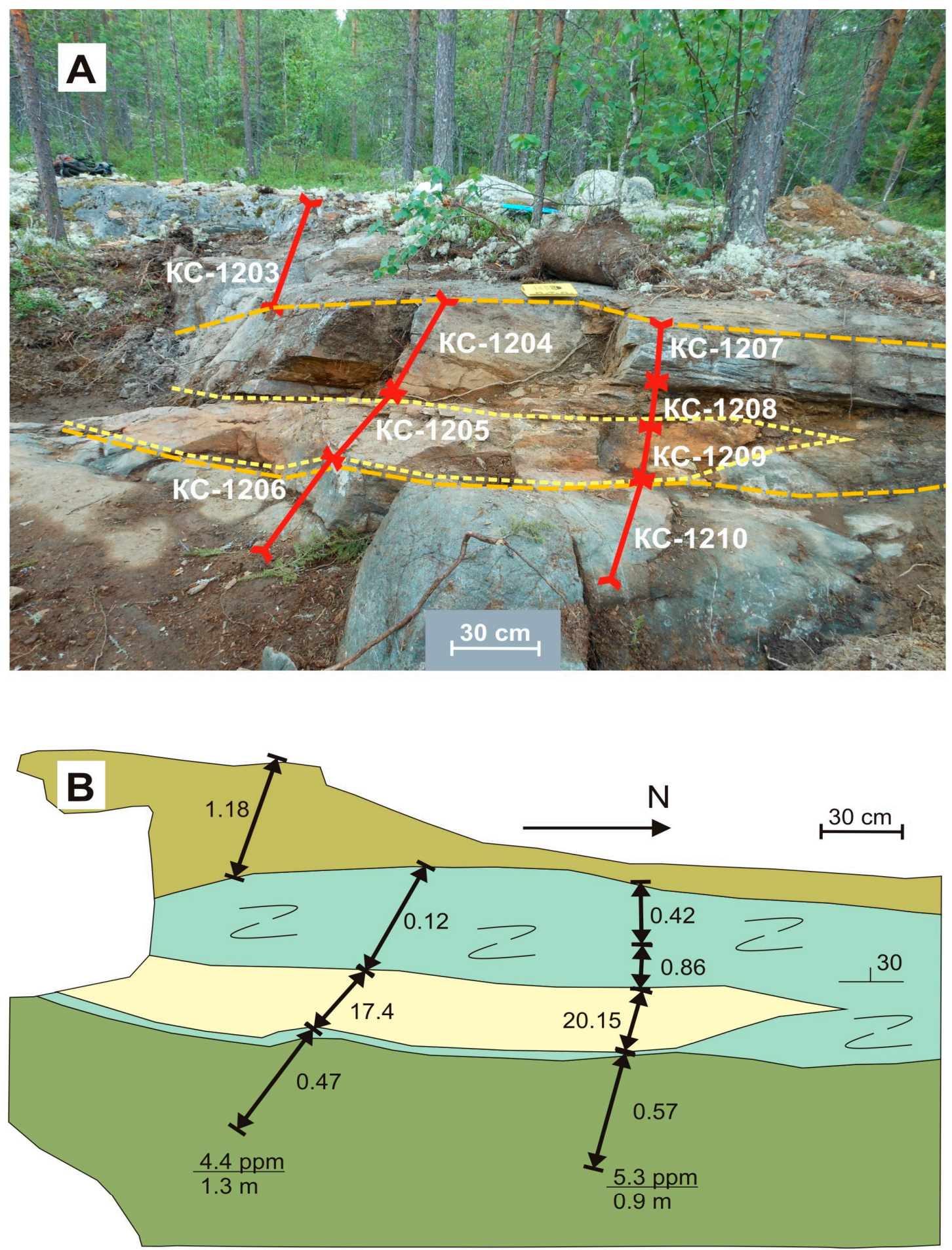

$\square$ hornblende-garnet amphibolite

$\square$ hornblende plagioamphibolite

zone of foliation and schistosity in the hornblende-garnet amphibolite quartz metasomatic rock after hornblende-garnet amphibolite

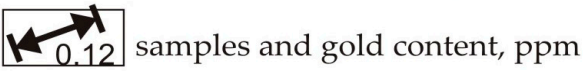

30 schistosity in the amphibolite

Figure 13. The Kichany gold occurrence. (A) Photo of the outcrop, with location of trench samples; (B) documentation of the same outcrop, with the results of assaying for gold. 
Gold forms inclusions in silicate minerals (hornblende, oligoclase, titanite) in quartz, then it was noted at the boundary of sulfides (arsenopyrite and marcasite) with quartz, and less frequently, in inclusions in pyrrhotite and chalcopyrite (Figure 14).

Gold is fine-grained, mainly less than $0.1 \mathrm{~mm}$. Grains are xenomorphic lumpy, or idiomorphic hexahedral. Some grains are spongy due to numerous quartz inclusions. Gold fineness is high (890-913), it makes alloys with silver; other impurities (Fe, Cu, Zn, Hg, As, Sb) were not detected.

Age of titanite ( $\mathrm{U}-\mathrm{Pb}$ method) from the silicified amphibolite with gold-arsenopyrite mineralization, which contains inclusions of gold (Figure 14c), is $1739 \pm 15 \mathrm{Ma}$ [28]. Mineralization either formed or was re-mobilized in the Paleoproterozoic during the Svecofennian metamorphic event.

Table 8. Chemical composition of mineralized rocks of the Kichany gold occurrence, the Tiksheozero belt, mas. $\%$.

\begin{tabular}{ccccccccc}
\hline Sample \# & KC-1203 & KC-1204 & KC-1104A & KC-1205 & KC-1104 & KC-1206 & KC-1210 & KC-1054 \\
\hline $\mathrm{SiO}_{2}$ & 53.51 & 52.91 & 63.28 & 64.93 & 84.14 & 47.29 & 49.06 & 40.49 \\
$\mathrm{TiO}_{2}$ & 1.44 & 1.73 & 0.81 & 1.13 & 0.27 & 0.65 & 0.65 & 1.85 \\
$\mathrm{Al}_{2} \mathrm{O}_{3}$ & 13.76 & 14.27 & 8.74 & 8.63 & 4.07 & 10.99 & 10.99 & 17.21 \\
$\mathrm{Fe}_{2} \mathrm{O}_{3}$ & 0.89 & 2.3 & 4.53 & 0.86 & 0.84 & 1.23 & 1.09 & 5.56 \\
$\mathrm{FeO}$ & 9.99 & 9.65 & 7.09 & 8.67 & 4.64 & 9.23 & 9.52 & 7.08 \\
$\mathrm{MnO}$ & 0.16 & 0.18 & 0.06 & 0.086 & 0.04 & 0.23 & 0.22 & 0.19 \\
$\mathrm{MgO}$ & 4.79 & 4.44 & 1.96 & 3.71 & 1.05 & 12.96 & 10.4 & 3.46 \\
$\mathrm{CaO}$ & 7.98 & 7.57 & 3.72 & 4.56 & 1.67 & 11.32 & 11.79 & 18.81 \\
$\mathrm{Na}_{2} \mathrm{O}$ & 2.69 & 2.96 & 1.98 & 1.58 & 0.92 & 1.4 & 1.55 & 0.96 \\
$\mathrm{~K}_{2} \mathrm{O}$ & 0.79 & 0.85 & 0.47 & 0.47 & 0.25 & 0.56 & 0.57 & 0.21 \\
$\mathrm{H}_{2} \mathrm{O}^{-}$ & 0.44 & 0.14 & 0.26 & 0.47 & 0.14 & 0.16 & 0.18 & 0.27 \\
$\mathrm{H}_{2} \mathrm{O}^{+}$ & 1.84 & 1.86 & 1.35 & 2.07 & 0.69 & 2.56 & 2.36 & 2.55 \\
$\mathrm{~S}$ & 0.90 & 0.29 & 3.01 & 1.92 & 1.07 & 0.03 & 0.30 & 0.23 \\
$\mathrm{CO} \mathrm{N}_{2}$ & 0.53 & 0.43 & $<0.10$ & $<0.10$ & $<0.10$ & 0.23 & 0.22 & 0.73 \\
$\mathrm{P}_{2} \mathrm{O}_{5}$ & 0.06 & 0.07 & n.a. & 0.03 & n.a. & 0.02 & 0.02 & 0.15 \\
$\mathrm{~F}$ & 0.013 & 0.013 & 0.009 & 0.009 & 0.005 & 0.015 & 0.013 & 0.016 \\
$\mathrm{Cl}$ & 0.027 & 0.033 & 0.005 & 0.015 & 0.008 & 0.012 & 0.017 & 0.017 \\
$\mathrm{As}$ & n.a. & n.a. & 2.86 & n.a. & 0.053 & n.a. & n.a. & n.a. \\
$\mathrm{Total}_{\mathrm{Au}}$ & 99.82 & 99.71 & 100.14 & 99.15 & 99.86 & 98.90 & 98.96 & 99.78 \\
$\mathrm{ppm}$ & 1.18 & 0.12 & 31.22 & 17.4 & 2.76 & 0.47 & 1.44 & n.a. \\
\hline
\end{tabular}

Notes: n.a. = not analysed; KC-1203, KC-1204-hornblende-garnet amphibolite; KC-1104A, KC-1205-silicified hornblende-garnet amphibolite; KC-1104—quartz metasomatite after amphibolite; KC-1206, KC-1210—hornblende plagioamphibolite; KC-1054-diopside-epidote-calcite-garnet metasomatite (skarnoid) after amphibolite.

\subsection{Gold in BIF Deposits in the Olenegorsk Greenstone Belt}

Rocks of the banded iron formations are known in all Precambrian shields in greenstone belts of Archean and Paleoproterozoic age (3.0-2.3 Ga), including in Canada, Australia, South America, South Africa, in the Ukranian Shield and Voronezh Crystalline Massifs in Europe, etc., and the Fennoscandian Shield is no exception. Globally, some gold-bearing BIF deposits contain up to 10-16 ppm in BIF deposits in the São Francisco Craton (Brazil), up to 8-14 ppm in the Yilgarn Craton, and up to $10 \mathrm{ppm}$ in Slave and Superior Provinces in North America. Gold mineralization is intrinsic to the BIF deposits rich in sulfides-to magnetite-sulfide, silicate-sulfide, carbonate-sulfide, and other facies of ferriginous quartzite [29].

In the Kola region, only two of nine iron-producing BIF deposits in the Olenegorsk belt were studied for gold - the Olenegorskoe (more details following) (\#5 in Figure 1) and the Kirivogorskoe [29-31]. High gold grades in the Olenegorskoe deposit were found in magnetite-sulfide quartzite in the area with numerous pegmatite, pegmatite granite, and metagabbrodiorite veins. Thickness of the zone, enriched in gold, is $18-30 \mathrm{~m}$, average gold grade is $1.36 \mathrm{ppm}$ (for $18 \mathrm{~m}$ thickness), but in some samples, gold content reaches $5.5 \mathrm{ppm}$ [29].

Aside from that, gold mineralization was found in the areas of intense calcium metasomatism in both the Olenegorskoe and Kiriovogorskoe deposits in skarnoids and hydrothermal metasomatic veins. Skarnoids (mineral assemblages, similar to skarn, but not connected with carbonate rocks and granitic magmatism) in the Olenegorskoe deposit develop at the boundary of magnetite-sulfide 
quartzite and high-alumina biotite gneiss, these metasomatic rocks consist of ferropargasite, Ca-rich almandine, epidote, calcite, quartz, and sulfides in different proportion [31]. In the Kirovogorkoe deposit skarnoids are of diopside-magnetite mineral composition.
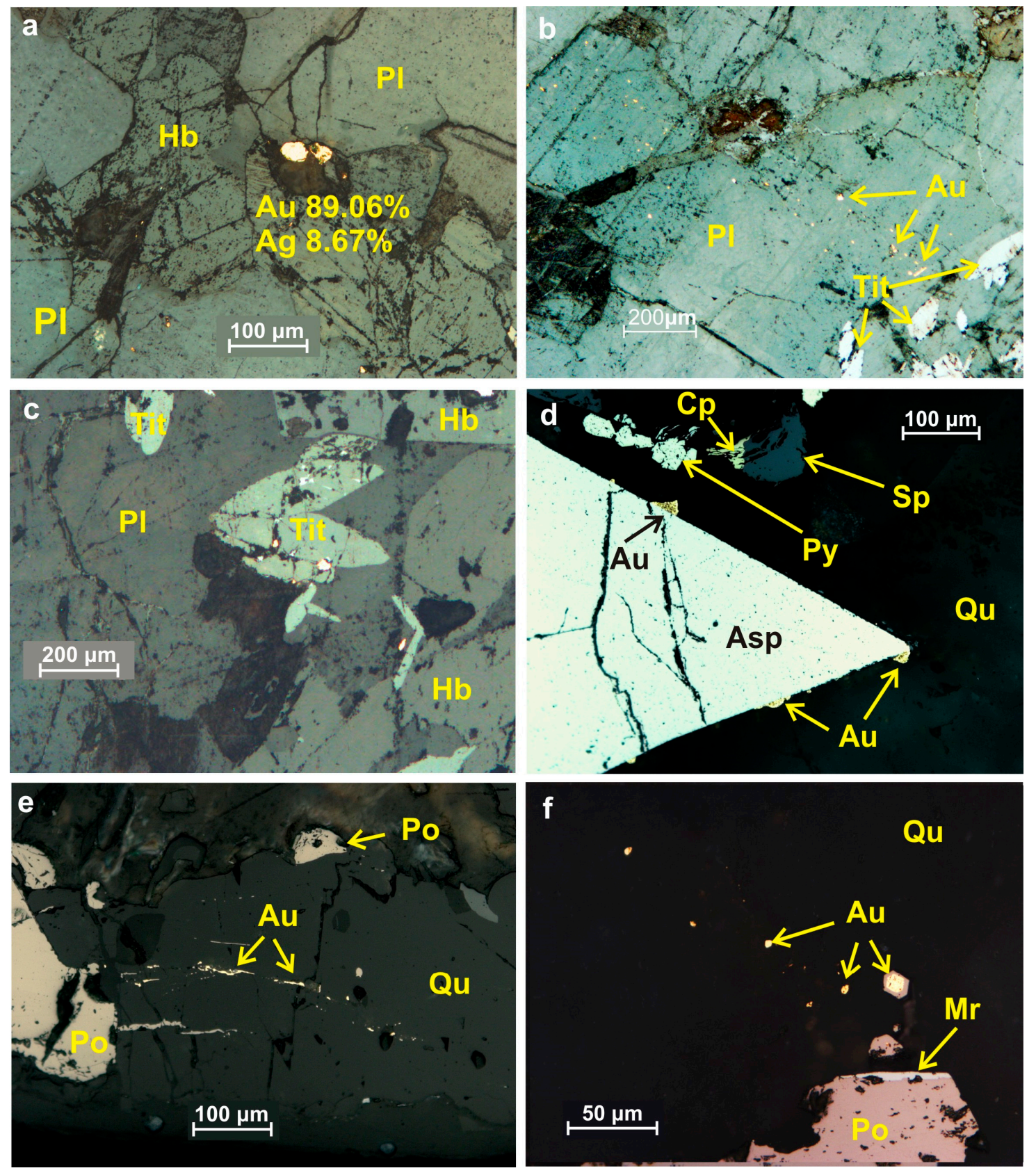

Figure 14. Gold in the Kichany occurrence, polished section photo, reflected light, one polarizer. (a) gold at the boundary plagioclase-hornblende, with the results of microprobe analysis, (b) a series of gold inclusions in plagioclase, (c) gold in titanite, (d) gold at the boundary of arsenopyrite metacrystal and quartz, (e) gold in fissures in quartz, and (f) gold in quartz, hexahedral gold grain is overgrown by pyrrhotite.

Hydrothermal metasomatic in 50-80 cm thick veins were found in the magnetite-sulfide quartzite, in the high-alumina biotite gneiss, and in the skarnoids. Quartz veins are the most common, in addition calcite, diopside-calcite, quartz-biotite-almandine, and hornblende-almandine veins were defined [32]. 
The skarnoids and hydrothermal veins contain sulfide mineralization (pyrrhotite, pyrite, chalcopyrite, less frequently galena, sphalerite, molybdenite) with electrum $\left(\mathrm{Au}_{0.39-0.56} \mathrm{Ag}_{0.33-0.51}\right.$ $\mathrm{Fe}_{0.03-0.18}-\mathrm{Ag}_{0.70} \mathrm{Au}_{0.25} \mathrm{Fe}_{0.05}$ ), native copper and bismuth, and Bi-tellurides. Electrum forms flakes flattened or wire-like grains in intergrowths with quartz, magnetite, hornblende, sulfides.

Age of zircon from the mineralized hydrothermal veins falls into interval 2645-2675 Ma (U-Pb method) [33], which is $\sim 35$ Ma younger than the zircon from the host biotite gneiss [33]; probably, sulfide mineralization with gold formed at the Neoarchean stage of regional metamorphism.

\subsection{South Pechenga Zone of the Pechenga Greenschist Belt}

The Pechenga belt is the best studied part of the Polmak-Pasvik-Pechenga-Imandra-Varzuga Paleoproterozoic belt system due to Pechenga group of Ni-Cu deposits in its northern part (Figure 1). Similar to other belts of the system, the Pechenga belt consists of two zones of metamorphosed sedimentary and volcanic sequences-the northern and southern [34]. The northern zones in the belts are characterized by weakly broken monoclinal sequences dipping at $20-60^{\circ}$, while in the southern zones the rocks are highly folded and faulted as a result of collision in the Late Paleoproterozoic [34]. Most of the Pechenga belt is a monocline formed by subconcordant sedimentary and volcanic sequences bounded by thrust faults plunging to the SSW. The oldest sequences are located in the north (footwall), and the youngest on the southern side.

Volcanic and tuffaceous sedimentary rocks of the Southern Pechenga structure, dated at 1.93-1.86 Ga, are localized within a long, but comparatively narrow tectono-stratigraphic area. The rocks are intensely folded and faulted and form a system of isoclinal folds overturned to the souteast, complicated by cross breaks and thrusts concordant to the general strike of the zone. The rocks are greenschist-lower amphibolite metamorphosed [35].

Points of gold mineralization $(>0.1 \mathrm{~g} / \mathrm{t} \mathrm{Au}$ ) were identified in different rocks in the belt $[36,37]$ : in andesitic related to the Por'itash igneous complex; in volcanogenic massive sulfide pyrite-pyrrhotite ores; in tectonized and altered carbonaceous sequences near the meridional faults; in chlorite-carbonate altered ultramafics (picrite, peridotite, and serpentinite); in carbonate-quartz veins; and in metasomatic quartzite. But only in metasomatic quartzite the gold content reaches 1-5 ppm (\#6 in Figure 1).

Location of metasomatic quartzite is governed by the intersection of northwestern-trending faults and thrusts (along the strike of the metasedimentary horizons) and later northeastern-trending faults (Figure 15). Metasomatic quartzite occurs as lenticular bodies with individual lenses less than 9-m thick, traced for a few tens of meters (up to $200 \mathrm{~m}$ ). Along strike, lenses can be replaced by zones of carbonate-quartz veining. Lenses of quartzite are often folded together with the host rocks and cut through by later faults.

The mineralogy of quartzite is relatively simple: quartz makes $80-98$ vol.\% of the rock, dolomite, and rare calcite $1-5$ vol.\%; interstices between quartz grains are filled with amphibole (actinolite or grunerite), chamosite, oligoclase-albite, magnetite, sulfide minerals, and less frequently, carbonaceous matter. Amphibole- (the most abundant), chlorite-amphibole-, chlorite-, and magnetite-bearing metasomatic quartzites are distinguished by the dominant $\mathrm{Fe}-\mathrm{Mg}$ mineral.

Sulfide-oxide disseminated mineralization (up to 3 vol.\%) was observed in quartzite from all locations except for the Porojarvinskoe. The mineral assemblage is composed by sulfides pyrrhotite, chalcopyrite, pyrite, arsenopyrite, sphalerite, and molybdenite (the last two minerals are sporadic), and by oxides (magnetite, ilmenite, rutile); native gold was also identified (Table 9). 


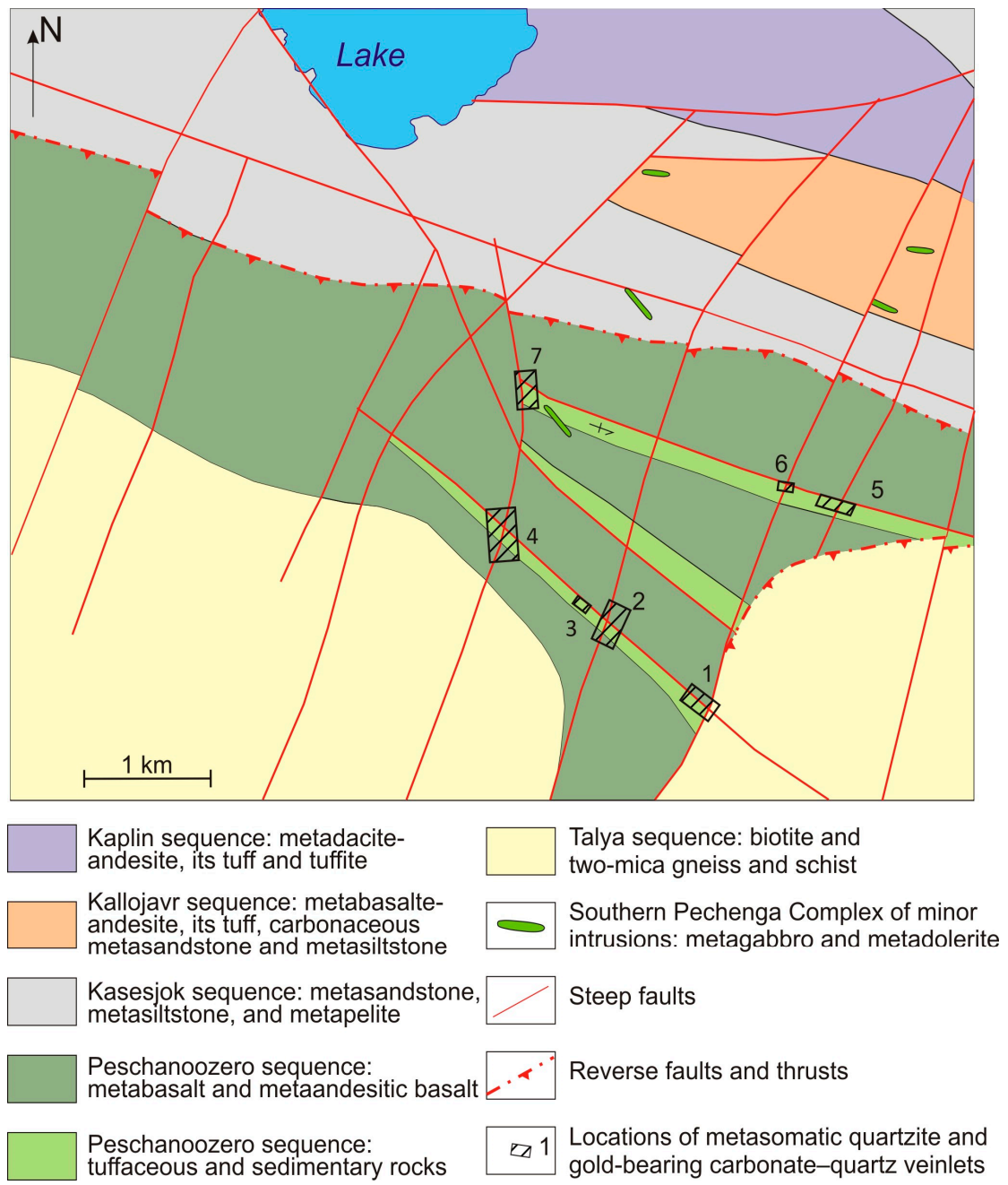

Figure 15. Schematic geological map of the Porojarvi area in the South Pechenga structure. Numerals are locations: (1) Timofeevsky, (2) Anomal'ny, (3) Zagadka, (4) Kontaktovy, (5) Svetlanovsky, (6) Istok, and (7) Porojarvinskoe.

Gold grades above $1 \mathrm{ppm}$ were measured in amphibole quartzite with sulfide mineralization (Timofeevsky, Kontactovy), and without it (Porojarvinskoe). The best section in the Timofeevsky is $1.2 \mathrm{ppm}$ for $3.2 \mathrm{~m}$, and $3.3 \mathrm{ppm}$ Au for $2.0 \mathrm{~m}$ in the Porojarvinskoe. Gold grains are fine $(<0.2 \mathrm{~mm})$, of irregular form.

Our study of fluid inclusions in quartz from mineralized rocks showed temperature of homogenization in the range $242-336{ }^{\circ} \mathrm{C}$, the composition of the fluid was $\mathrm{H}_{2} \mathrm{O}-\mathrm{CO}_{2}$ with minor methane, and low fluid salinity $0.4-3.8$ wt.\% $\mathrm{NaCl}$-equivalent, $\mathrm{Na}, \mathrm{Ca}, \mathrm{Mg}$, and $\mathrm{K}$ chlorides. The estimated fluid pressure is 1.20-2.58 kbar (Table 5).

Abundances of the main cations, measured by LA-ICP-MS [22], are the following (ppm): $\mathrm{Na}$ (983-4001), K (1055-6075), Mg (59-294), Ca (442-3176). It is interesting to note content of Ag (11.0-34) and $\mathrm{Au}$ (4.6-202) is relatively high in the fluid.

Isotope Sm-Nd study of quartz-albite-carbonate metasomatic rock with gold mineralization from the Zagadka location had a defined age of $1888 \pm 22 \mathrm{Ma}$ [38]. This age is consistent within the uncertainty limits, with the $\mathrm{Rb}-\mathrm{Sr}$ dating of the volcanic rocks of the Bragino (1865 $\pm 58 \mathrm{Ma}$ ) and Kaplin (1855 $\pm 54 \mathrm{Ma})$ sequences [40], which likely corresponds to the age of metamorphism. 
Table 9. General characteristics of gold occurrences in the Pechenga and Salla-Kuolajarvi greenstone belts.

\begin{tabular}{|c|c|c|c|}
\hline \multicolumn{2}{|c|}{ Deposit/Occurrence } & Porojarvi & Mayskoe \\
\hline \multicolumn{2}{|c|}{ Greenstone belt } & Pechenga, South Pechenga structure (PR) & Salla-Kuolajarvi (PR) \\
\hline \multicolumn{2}{|c|}{ Tectonic structure } & $\begin{array}{l}\text { Intersection of northwestern and northeastern } \\
\text { fault systems }\end{array}$ & $\begin{array}{l}\text { Quartz veins along dolerite and gabbropyroxenite } \\
\text { dykes filling northeastern faults }\end{array}$ \\
\hline \multicolumn{2}{|c|}{ Host rocks } & $\begin{array}{c}\text { Biotite and muscovite-biotite schists, } \\
\text { amphibole-chlorite and chlorite plagioschists, } \\
\text { amphibolite. }\end{array}$ & Metabasalt, metaandesite, and their tuffs \\
\hline \multicolumn{2}{|c|}{ Regional metamorphism } & $\begin{array}{l}\text { Paleoproterozoic } \sim 1.9 \mathrm{Ga} \text {, upper greenschist- } \\
\text { lower amphibolite }\end{array}$ & Paleoproterozoic $\sim 1.9 \mathrm{Ga}$, upper greenschist \\
\hline \multirow{3}{*}{$\begin{array}{l}\text { Alteration, assemblages } \\
\text { of new formed minerals }\end{array}$} & -pre-ore & Chlorite-carbonate (propylitization) & $\begin{array}{l}\text { Regional propylitization, Mg-metasomatism } \\
\text { (Mg-amphibole-biotite-quartz, chlorite) }\end{array}$ \\
\hline & -gold-related & $\begin{array}{c}\mathrm{Si}\left(\mathrm{CO}_{2}\right) \\
\text { Quartz-cummingtonite and } \\
\text { quartz-cummingtonite-chlorite, } \\
\text { quartz-albite-carbonate, stockwork of } \\
\text { quartz-carbonate veinlets }\end{array}$ & $\begin{array}{c}\text { K-Ba-Si } \\
\text { Quartz-carbonate-feldspar (K-Ba) }\end{array}$ \\
\hline & -post-ore & Not defined & Not defined \\
\hline \multicolumn{2}{|c|}{ Mineralized bodies } & $\begin{array}{c}\text { The best cross section is } 3.3 \mathrm{ppm} \text { Au for } 2.0 \mathrm{~m} \text { in } \\
\text { a trench by CKE }\end{array}$ & $\begin{array}{l}\text { Ore shoots in quartz veins:vein \#1: ore shoot length } \\
110 \mathrm{~m}, \mathrm{Au} 13.1 \mathrm{ppm} \text {;vein \#40: ore shoot length } 80 \mathrm{~m} \text {, } \\
\text { Au } 10.5 \mathrm{ppm}\end{array}$ \\
\hline \multicolumn{2}{|c|}{$\begin{array}{l}\text { Texture of mineralization, sulfide } \\
\text { content (vol.\%) }\end{array}$} & $\begin{array}{l}\text { Disseminated and nested-disseminated in } \\
\text { quartzite and in carbonate-quartz veinlets, } 0-2\end{array}$ & $\begin{array}{l}\text { Streaky and disseminated in quartz veins and vein } \\
\text { exocontacts, } 1-2\end{array}$ \\
\hline \multicolumn{2}{|c|}{ Main ore minerals } & Arsenopyrite, pyrrhotite & Chalcopyrite, pyrite, sphalerite \\
\hline \multicolumn{2}{|c|}{ Minor ore minerals } & Magnetite, chalcopyrite, rutile, pyrite. & $\begin{array}{l}\text { Galena, magnetite, cobaltite, marcasite, bornite, gold, } \\
\text { sheelite, cobaltpentlandite, } \mathrm{Bi}-\mathrm{Pb} \text { tellurides }\end{array}$ \\
\hline \multicolumn{2}{|c|}{ Geochemical association, ratio $\mathrm{Au} / \mathrm{Ag}$} & $\begin{array}{c}\mathrm{Au}-\mathrm{As} \\
\mathrm{Au} / \mathrm{Ag}=4-10\end{array}$ & $\mathrm{Ag}-\mathrm{Cu}-\mathrm{Pb}-\mathrm{Au}(\mathrm{Zn}, \mathrm{Co}, \mathrm{Mo}, \mathrm{Te}, \mathrm{W})$ \\
\hline \multicolumn{2}{|c|}{ Age of mineralized rocks } & $\begin{array}{l}\text { Sm-Nd isochrone age of quartz-albite-carbonate } \\
\text { rock with gold mineralization } 1888 \pm 22 \mathrm{Ma} \text { [38] }\end{array}$ & $\begin{array}{c}\text { Propylitization } 1770 \pm 9 \mathrm{Ma}(\mathrm{Rb}-\mathrm{Sr} \text { isochrone) }(9610 \\
\pm 30 \mathrm{Ma} \text { [23]), Gold from ore shoots (Re-Os } \\
\text { isochrone) } 397 \pm 15 \mathrm{Ma} \text { [39] }\end{array}$ \\
\hline \multicolumn{2}{|c|}{ Gold characteristics, fineness in \%o } & $\begin{array}{c}\text { Fine }(<0.05 \mathrm{~mm}) \text { gold inclusions in arsenopyrite } \\
\text { and in quartz. } \\
\text { Gold fineness } 790-800\end{array}$ & $\begin{array}{c}\text { Native gold in fissures in quartz, in aggregates with } \\
\text { chalcopyrite and galena. } \\
\text { Gold fineness } 900-940\end{array}$ \\
\hline
\end{tabular}

\subsection{The Salla-Kuolajarvi Belt}

The Salla-Kuolajarvi belt is a member of the Lapland-Karelian Paleoproterozoic greenschist belt system (Figure 1). Similar to the Pechenga and Imandra-Varzuga belts, and the Salla-Kuolajarvi belt is of asymmetric structure. The eastern zone (the Russian part) has a simple cross-section with rock sequences dipping west at an angle of $10^{\circ}$ (in the center of the belt) to $70^{\circ}$ (in the flank). The western part of the belt, in Finland, is represented by a set of granitized tectonic slabs (blocks), each block has its own structure [41].

Volcanic-sedimentary rocks in the Russian part formed in Jatulian (2.3-2.1 Ga) and Ludikovian (2.1-1.92 Ga), older rocks (Sumian-Sariolian, 2.5-2.3 Ga) are known only in the southeastern part of the belt [41].

The small deposit of Mayskoe (\#8 in Figure 1), the only gold deposit ever mined in the region, is located in the central part of the Salla-Kuolajarvi belt. Quartz veins in the deposit are hosted by metavolcanics of the Apajarvi Formation (basalt, andesite, and mafic tuffs), intruded by dolerite dykes and ultramafic sills (Figure 16). The dykes are controlled by northeast trending faults and form two sub-parallel bodies, dipping nothwest at an angle of $60-80^{\circ}$. The faults reveal in 5-10 m thick zones of schistosity, foliation, and jointing. The same northeast trending faults control zones of pre-vein metasomatic alteration and location of two quartz veins (veins \#1 and \#40), i.e., the faults play the role of ore-hosting tectonic structures.

The wallrocks underwent processes of propylitization, $\mathrm{Mg}$-metasomatism ( $\mathrm{Mg}$-amphibolebiotite-quartz assemblage and chloritization), and Si-K-Ba metasomatism (formation of quartz-K-Ba-feldspar-carbonates assemblage) [23,42]. Propylitic alteration is of regional character; but $\mathrm{Mg}$ and $\mathrm{Si}-\mathrm{K}-\mathrm{Ba}-\mathrm{metasomatism}$ occur only within the vein-hosting fault zones. Quartz veins contain numerous xenoliths of intensely altered host metabasalt and metapyroxenite. 


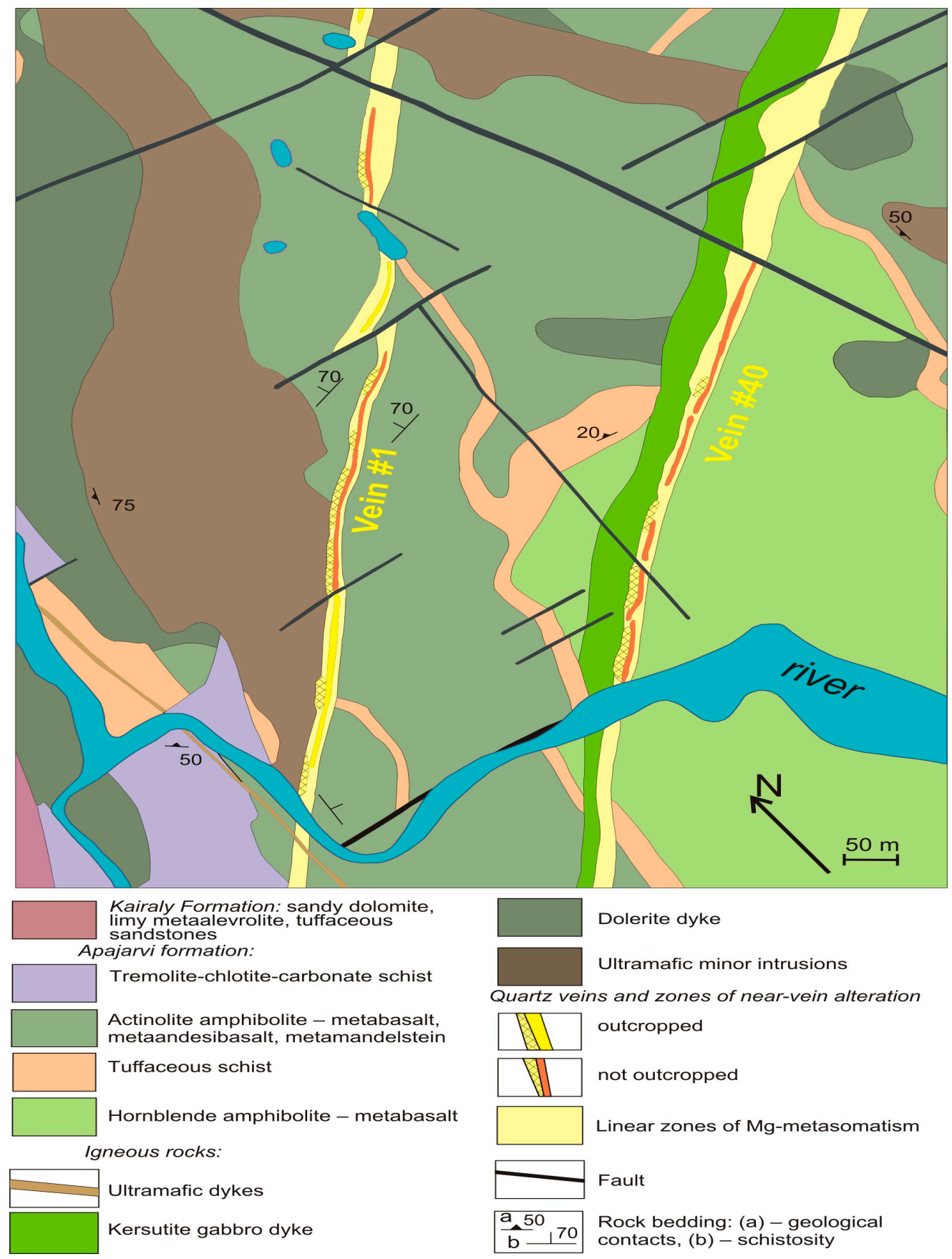

Figure 16. Schematic geological map of the Mayskoe deposit (modelled from Reference [23]).

Nested and veinlet sulfide mineralization is located mainly close to the vein selvages, or at the contact with xenoliths. Ore mineral assemblage includes chalcopyrite, pyrrhotite, sphalerite, galena, pyrite, cobaltite, native gold, sporadically $\mathrm{Pb}$ and $\mathrm{Bi}$ tellurides and selenides $[43,44]$, and oxide minerals are rutile and scheelite. The metal association can be described as $\mathrm{Ag}-\mathrm{Cu}-\mathrm{Pb}-\mathrm{Au}(\mathrm{Zn}-\mathrm{Co}-\mathrm{Te}-\mathrm{W})$.

Gold in the veins is distributed unevenly. Ore shoots are localized in those parts of the veins, which are of complicated morphology, with xenoliths, intensely jointed, and with granular quartz. Ore shoots are $20-30 \mathrm{~m}$ in vertical section (80-110 $\mathrm{m}$ long on the surface), northeastern declines are at an angle of $15-20^{\circ}$. The gold grade is $13.1 \mathrm{ppm}$ in the ore shoot of vein \#1, and $10.5 \mathrm{ppm} \mathrm{Au}$ in vein \#40. 
Visible gold was noted in fractures in quartz, often in intergrowths with galena and sphalerite. Grains of gold are of irregular flattened form, rounded, hexahedral. The gold fineness is high (900-960). The study of fluid inclusions are shown in the following (Table 5) [23]:

- The temperature of homogenization of fluid inclusions in quartz from propylite is $350-430{ }^{\circ} \mathrm{C}$. The fluids have very high salinity (up to 25-35 wt.\% NaCl-equivalent), and its composition changed in time from $\mathrm{NaCl}$ to $\mathrm{MgCl}$.

- The temperature of homogenization of fluid inclusions in non-mineralized quartz is $300-350{ }^{\circ} \mathrm{C}$, the composition of the fluid is $\mathrm{H}_{2} \mathrm{O}-\mathrm{NaCl}$, the salinity is moderate, $3-7 \mathrm{wt} \% \mathrm{NaCl}$-equivalent

- In granular quartz with gold mineralization the temperature of homogenization of fluid inclusions is $190-270{ }^{\circ} \mathrm{C}$, the fluid composition is $\mathrm{CO}_{2}-\mathrm{CH}_{4}$ with very high methane content from $16-25$ to 62-70 mas.\%, increasing with the approach to the chalcopyrite grain; the salinity of the fluid is high with $22-28 \mathrm{wt} . \% \mathrm{CaCl}_{2}$-equivalent, $\mathrm{CaCl}_{2}$ dominates. The pressure is estimated at $0.5-0.94 \mathrm{kbar}$.

Isotope dating showed multi-stage history of mineralization development. Pre-ore propylites formed $1770 \pm 9 \mathrm{Ma}(\mathrm{Rb}-\mathrm{Sr}$, minerals and rock) [45]. Age of Mg-metasomatism is $1610 \pm 30 \mathrm{Ma}$ ( $\mathrm{Rb}-\mathrm{Sr}$, minerals and rock) [39]. K-Ar age of feldspar in Si-K-Ba metasomatite was estimated $1380 \pm 40$ Ma [23]. Finally, Re-Os age of gold is $397 \pm 15 \mathrm{Ma}$ [39].

\section{Distribution and Timing of Formation of Gold Deposits in the Northeastern Part of the FenNoscandian Shield}

Nearly all gold deposits, occurrences, and points of mineralization (75 of 80 points of mineralization with $>1$ ppm gold), known in metamorphic complexes in the Kola region and shown in Figure 1, are located within the Neoarchean and Paleoproterozoic greenstone belts. The distribution of gold occurrences is uneven; not all greenstone belts contain gold mineralization and the most prolific are the Kolmozero-Voron'ya and Strel'na belts, then the Olenegorsk belt and South Pechenga. According to genetic grouping of the belts [8], shown in Figure 1, the Kolmozero-Voron'ya belt is a paleosuture, other aforementioned belts are rift-related.

The locations of the deposits and occurrences are controlled by regional tectonic zones at the boundaries of major segments of the Fennoscandian Shield. One of these zones is the system of Neoarchean greenstone belts Kolmozero-Voron'ya-Ura-guba along the Murmansk craton-Kola-Norwegian terrane boundary (Figures 1 and 2). This tectonic structure includes the deposits Oleninskoe and Nyal'm and more than 20 occurrences and points of gold mineralization with $>1$ ppm gold.

Another important tectonic structure is a suture, delineating the core of the Lapland-Kola orogen in the north (Figure 2), composed of a series of overthrusts. This zone includes the Sergozerskoe deposit and gold occurrence Vorgovy in the Strel'na belt, Porojarvi occurrence in the South Pechenga structure, and more than 20 points of gold mineralization.

The third tectonic structure to be mentioned here is the series of overthrusts and faults at the eastern flank of the Salla-Kuolajarvi belt, traced farther southeast along the northern boundary of the Lapland-Karelian system of the Paleoproterozoic belts (Figure 1).

The primary composition of rocks, hosting gold mineralization in the deposits and occurrences in the region, is variable:

- Mafic-ultramafic metavolcanics play a principal role in the Oleninskoe, Sergozerskoe, Mayskoe deposits, and in the Kichany gold occurrence (Tiksheozero belt).

- Metasedimentary terrigenous rocks host gold mineralization in BIF deposits of the Olenegorsk group, in the Porojarvi occurrence (South Pechenga), and in the Vorgovy occurrence (the Strel'na belt).

- Diorite porphyry intrusion hosts mineralization in the Nyal'm deposit. Except the Nyal'm, diorite porphyry dykes in mafic volcanics contain gold mineralization in the Oleninskoe and 
Sergozerskoe deposits, but it is unclear if these dykes play any role in mobilization and/or deposition of gold.

The metamorphic grade of mineralized rocks in the studied deposits varies from greenschist (in the central part of the Salla-Kuolajarvi belt) to upper amphibolite facies (the Tiksheozero and Olenegorsk belts), but mainly they are metamorphosed at lower amphibolite grade, close to the transition from greenschist to amphibolite facies (the Kolmozero-Voron'ya, Strel'na, South Pechenga, eastern flank of the Salla-Kuolajarvi belt) (Figure 17).

Under the conditions of transition from greenschist to amphibolite facies, the modal mineralogy of rocks and bulk-rock volatile content change, and consequently, favorable conditions for gold mobilization and migration emerge [46]. In the Paleoproterozoic belts with zonal metamorphism, the majority of occurrences and points of mineralization are located in the tracts of greenschist-amphibolite transition in the marginal part of the belts (occurrences in the South Pechenga structure and at the eastern flank of the Salla-Kuolajarvi belt) (Figure 17).

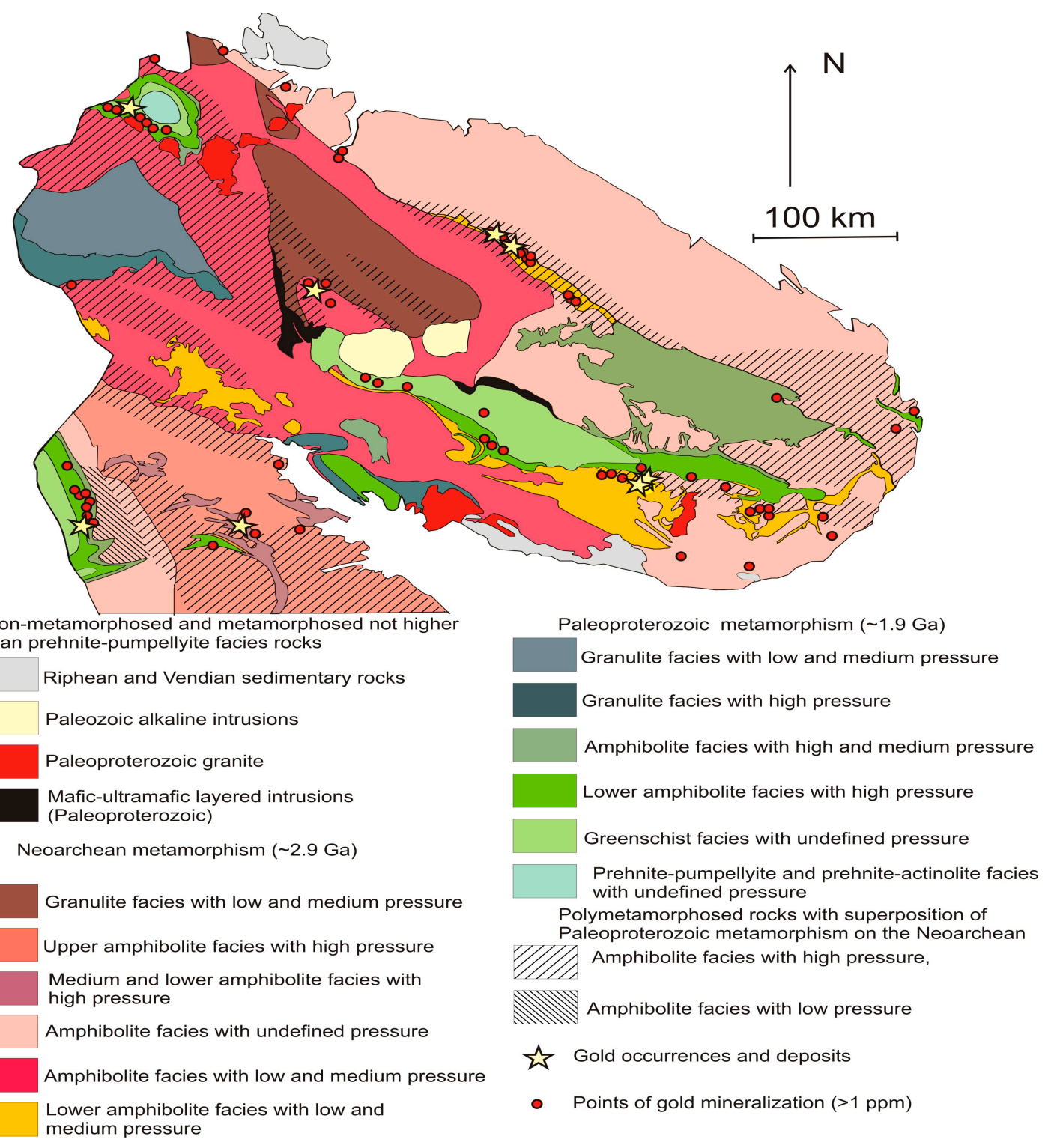

Figure 17. Distribution of gold deposits and occurrences in the schematic map of mineral facies of metamorphic rocks in the northeastern part of the Fennoscandian Shield (Modified from Reference [47]). 
The Kolmozero-Voron'ya and Strel'na belts, two structures, which are the richest in gold mineralization, are low amphibolite high-gradient (high temperature, low pressure) metamorphosed. Moderate-to-high geothermal gradients are known to be favorable for the formation of gold deposits in metamorphic rocks [46].

The wallrocks were intensely altered in all studied deposits. Calcium rich minerals formed during pre-ore alteration in amphibolite metamorphosed complexes, the mineral assemblages include Ca-amphiboles (actinoliote, pargasite) and pyroxene (diopside), epidote-zoisite, Ca-rich almandine, calcite, and other carbonates (Oleninskoe, Kichany, Olenegorsk BIF deposits). Propylitization was the most common pre-ore alteration in the greenschist metamorphosed complexes, where mineral assemblage of chlorite, carbonate, and quartz formed. Gold-related alteration in the studied deposits was of a $\mathrm{Si}-\mathrm{CO}_{2}-\mathrm{K}$ character, with development of quartz, carbonate, biotite and/or sericite, and sulphide mineral assemblages.

Three groups of fluids inclusions were defined in quartz from the studied gold deposits (Table 5):

- Fluids of $\mathrm{H}_{2} \mathrm{O}-\mathrm{CO}_{2}$ composition with low (0.4-7.7 wt.\% NaCl-equivalent) salinity (Nyal'm, Porojarvi, vein quartz in Mayskoe deposit).

- Fluids of $\mathrm{H}_{2} \mathrm{O}-\mathrm{CO}_{2}$ composition with high (13-35 wt.\% NaCl-equivalent) salinity (Oleninskoe, quartz from propylite in Mayskoe deposit).

- Fluids of $\mathrm{CH}_{4}-\mathrm{CO}_{2}$ composition with high salinity 22-28 wt.\% NaCl-equivalent (quartz with gold in Mayskoe deposit).

Fluids of $\mathrm{H}_{2} \mathrm{O}-\mathrm{CO}_{2}$ composition with low salinity are favorable for formation of gold-only deposits in metamorphic complexes, because these fluids are able to mobilize Au from metamorphosed rocks and transport it in a form of Au-S complexes, but the content of base metals in these fluids is low [46,48]. Earlier we noted very high Au concentrations up to $202 \mathrm{ppm}$ in fluids in the Porojarvi occurrence [39].

Fluids with high salinity do not form during regional metamorphism of the rocks, and they are probably connected with some magmatic source. In the Oleninskoe deposit, this magmatic source may be that one, which produced quartz porphyry dykes. In the Mayskoe, the presence of a large granite body at depth is likely due to a big negative gravity anomaly in the area of the deposit.

Fluids with high salinity can transport gold in chloride complexes, and these fluids are enriched in base metals as well $[46,48,49]$. Additional studies are needed to understand the origin of the fluids with extremely high methane and high salinity.

The main sulfide minerals in all gold deposits and occurrences in the region are arsenopyrite and pyrrhotite, with the only exception of the Mayskoe, where chalcopyrite prevails, and arsenic minerals are cobaltite and gersdorfite. Pyrite is not common in the deposits probably due to relatively high levels of metamorphism, when pyrrhotite formed instead of pyrite [50].

The geochemical association of metals ( $\mathrm{Au}-\mathrm{As})$, and consequently, mineral composition of the ores are relatively simple in the deposits, which formed from $\mathrm{H}_{2} \mathrm{O}-\mathrm{CO}_{2}$ fluids with low salinity and low concentration of base metals (Nyal'm, Porojarvi, probably Vorgovy, Sergozerskoe, Kichany). In the deposits with high fluid salinity (the Oleninskoe and Mayskoe) the metal association includes $\mathrm{Au}-\mathrm{Ag}-\mathrm{As}-\mathrm{Cu}-\mathrm{Pb}-\mathrm{Zn}$, and different $\mathrm{Ag}$ and base metal sulfides and $\mathrm{Pb}, \mathrm{Ag}$, and Bi tellurides play an important role in the mineral composition of the ore.

Gold deposits and occurrences in greenstone belts in the northeastern part of the Fennoscandian Shield (including Finnish Lapland) formed during two main periods, one in the Neoarchean, and another one in the Paleoproterozoic, both periods related to global collision events (Table 10), which coincided with the main peaks of gold deposit formation worldwide [51].

During the period 2.72-2.64 Ga, when a few Archean microcontinents consolidated and formed the supercontinent Kenorland, gold deposits Oleninskoe and Nyal'm formed in the Kolmozero-Voron'ya belt in between the Murmansk and Inari-Kola microcontinents under conditions 
of "continent-continent" collision. At the same period of time, gold mineralization formed in BIF deposits in the Olenegorsk belt.

In the Paleoproterozoic, two stages of formation of gold deposits were defined; these stages are connected with consolidation of separated fragments of the Kenorland (with accreted greenstone belts) into new supercontinent Columbia. "Arc-continent" collision occurred 1.86-1.93 Ga in the Pechenga-Imandra-Varzuga and Central Lapland rift-related greenschist belts. At this stage, gold deposits and occurrences formed along Sirkka and Kiistola shear zones in the Central Lapland belt in Finland (including Suurukuusikko deposit, the biggest in the Europe), and in the Porojarvi area in the Southern Pechenga.

At the final phase of Columbia supercontinent consolidation, 1.87-1.70 Ga, intracontinental collision events resulted in development of the Lapland-Kola-Belomorian orogeny. During this stage gold deposits and occurrences formed not only in Paleoproterozoic belts (in Kuusamo and Peräpohja schist belts in Finland), but in reworked Neoarchean greenstone belts (Strel'na and Tiksheozero greenstone belts).

The Mayskoe deposit has a long and complicated history of development. The stage 1.87-1.70 Ga is revealed only in pre-ore regional propylitization, and other metasomatic processes are dated to be Middle Proterozoic (1.6-1.4 Ga). The Re-Os age of gold $397 \pm 15 \mathrm{Ma}$ [39] corresponds to the time of the Paleozoic tectonic activization and formation of alkaline ultramafic intrusions in the Kola region, but this dating needs to be verified, and may not actually be the time of formation of the deposit, but rather the time of gold recrystallization.

Table 10. The main stages of formation of gold and gold-bearing deposits and occurrences in the northeastern part of the Fennoscandian Shield (based on data from References [8,32,52]).

\begin{tabular}{|c|c|c|c|c|}
\hline Geodynamic Conditions & $\begin{array}{l}\text { Time } \\
\text { Interval, } \\
\text { Ga }\end{array}$ & $\begin{array}{l}\text { Geological Structures } \\
\text { (Greenstone Belts, } \\
\text { Intrusions) }\end{array}$ & Metallogenic Events & Deposits and Occurrences \\
\hline $\begin{array}{c}\text { Formation of core of the Murmansk, } \\
\text { Inari-Kola, Khetolambina } \\
\text { microcontinents }\end{array}$ & $>2.93$ & & & \\
\hline $\begin{array}{l}\text { Formation of ancient island arc } \\
\text { systems and their accretion to } \\
\text { microcontinents }\end{array}$ & $2.88-2.77$ & $\begin{array}{l}\text { Kolmozero-Voron'ya belt } \\
\text { (paleosuture), Central } \\
\text { Belomorian paleosuture, } \\
\text { Tiksheozero belt system }\end{array}$ & $\begin{array}{c}\text { Deposition of } \\
\text { volcanic-sedimenary rocks, } \\
\text { hosting epigenetic gold } \\
\text { mineralization and } \\
\text { gold-bearing quartz } \\
\text { conglomerates }\end{array}$ & \\
\hline $\begin{array}{l}\text { Formation of epigenetic rift } \\
\text { greenstone belts }\end{array}$ & $2.80-2.66$ & $\begin{array}{c}\text { Strel'na, Ura-Guba, } \\
\text { Allarechka, East Pansky, } \\
\text { Olenegorsk, etc. greensone } \\
\text { belts }\end{array}$ & $\begin{array}{c}\text { Deposition of } \\
\text { volcanic-sedimenary rocks, } \\
\text { hosting epigenetic gold } \\
\text { mineralization }\end{array}$ & \\
\hline \multirow{2}{*}{$\begin{array}{l}\text { Consolidation of microcontinents into } \\
\text { Kenorland supercontinent } \\
\text { ("continent-continent" collision) }\end{array}$} & \multirow{2}{*}{$2.72-2.64$} & Kolmozero-Voron'ya belt & \multirow{2}{*}{$\begin{array}{l}\text { Epigenetic gold deposits in } \\
\text { metamorphic complexes, } \\
\text { Mo-Cu porphyry deposits }\end{array}$} & $\begin{array}{l}\text { Oleninskoe, Nyal'm-1 }(\mathrm{Au}) \\
\text { Pellapahk }(\mathrm{Mo}-\mathrm{Cu})\end{array}$ \\
\hline & & Olenegorsk belt & & $\begin{array}{l}\text { Epigenetic Au mineralization } \\
\text { in BIF deposits }\end{array}$ \\
\hline $\begin{array}{l}\text { Rifting (mantle plume-initial stage } \\
\text { of Kenorland break) }\end{array}$ & $2.53-2.42$ & Fyodorovo-Pansky massif & $\begin{array}{l}\text { Layered mafic-ultramafic } \\
\text { intrusions (PGE, Ni-Cu } \\
\text { deposits) }\end{array}$ & $\begin{array}{c}\text { Fyodorova Tundra, Kievey, } \\
\text { N.Kamennik, E.Chuarvy, } \\
\text { Konttijarvi, Ahmavaara, } \\
\text { Pennikat }\end{array}$ \\
\hline $\begin{array}{c}\text { "Dormant tectonic" period } \\
\text { (sedimentation in intra-continental } \\
\text { basins) }\end{array}$ & $2.3-2.11$ & Salla-Kuolajarvi belt & $\begin{array}{c}\text { Deposition of } \\
\text { volcanic-sedimenary rocks, } \\
\text { hosting epigenetic gold } \\
\text { mineralization }\end{array}$ & \\
\hline \multirow{2}{*}{$\begin{array}{l}\text { Rifting and re-activization of } \\
\text { intra-continental basins, formation of } \\
\text { intra-continental rifts of Red Sea type } \\
\text { (mantle plume, break of Kenorland } \\
\text { supercontinent) }\end{array}$} & \multirow[t]{2}{*}{$2.11-1.92$} & Pechenga, Imandra-Varzuga & $\begin{array}{l}\text { Layered mafic- ultramafic } \\
\text { intrusions; intrusions of } \\
\text { gabbro-verlite formation }\end{array}$ & $\begin{array}{c}\text { Pechenga deposits }(\mathrm{Cu}, \mathrm{Ni}+ \\
\text { PGE, Au) (Zhdanovske, } \\
\text { Zapolyarnoe, etc.) }\end{array}$ \\
\hline & & $\begin{array}{l}\text { Salla-Kuolajarvi, Pechenga, } \\
\text { Imandra-Varzuga belts }\end{array}$ & $\begin{array}{c}\text { Deposition of volcanic } \\
\text {-sedimenary rocks, hosting } \\
\text { epigenetic gold mineralization }\end{array}$ & \\
\hline $\begin{array}{l}\text { Formation of Columbia } \\
\text { supercontinent; accretionary orogenes } \\
\text { of "igneous arc-continent" type }\end{array}$ & $1.93-1.86$ & S.Pechenga zone & Epigenetic gold deposits & $\begin{array}{c}\text { Occurrences in the Porojarvi } \\
\text { area }\end{array}$ \\
\hline $\begin{array}{l}\text { Intracontinental collisions of } \\
\text { "continent-continent" type; formation } \\
\text { of Lapland-Kola orogen }\end{array}$ & $1.87-1.7$ & $\begin{array}{l}\text { Strel'na belt } \\
\text { Tiksheozero belt }\end{array}$ & Epigenetic gold deposits & $\begin{array}{l}\text { Sergozero, Vorgovy } \\
\text { Kichany }\end{array}$ \\
\hline $\begin{array}{l}\text { Tectonic-magmatic activization in } \\
\text { Mesoproterozoic and Paleozoic }\end{array}$ & $<1.7$ & Salla-Kuolajarvi belt & Quartz-vein gold deposits & Mayskoe \\
\hline
\end{tabular}


The main prospects of the Kola region for new gold deposits are connected with the three abovementioned regional sutures. We can define four areas which have potential to become real goldfields in the case of successful exploration: the northwestern part of the Kolmozero-Voron'ya belt, the South Pechenga structure, the Strel'na belt at the northern flank of the Srel'na terrane, and the eastern flank of the Salla-Koulajarvi belt (Figures 1 and 2). The prospectivity is based on favorable geological conditions in terms of structures and due to numerous gold occurrences and minor deposits.

\section{Conclusions and Implications}

Gold deposits and occurrences in metamorphic complexes of the Kola region are located within the Neoarchean and Paleoproterozoic greenstone belts. The richest are the Kolmozero-Voron'ya and Strel'na belts, then the Olenegorsk belt and South Pechenga.

The location of the majority of deposits and occurrences is controlled by tectonic zones of regional scale at the boundaries of major segments of the Fennoscandian Shield: (1) the system of Neoarchean greenstone belts Kolmozero-Voron'ya-Ura-guba along the Murmansk craton-Kola-Norwegian terrane boundary, (2) a suture, delineating the core of the Lapland-Kola orogen in the north, and (3) the series of overthrusts and faults at the eastern flank of the Salla-Kuolajarvi belt, traced farther southeast along the northern boundary of the Lapland-Karelian system of Paleoproterozoic belts. The abovenamed suture zones are considered the most prospective for gold exploration in this region.

Gold deposits and occurrences in the northeastern part of the Fennoscandian Shield formed during two periods: in the Neoarchean at 2.7-2.6 Ga, and in the Paleoproterozoic at 1.9-1.7 Ga. According to paleo-geodynamic reconstructions these were the periods of collisional and accretionary orogeny in the region. The Archean greenstone belts, reworked in Paleoproterozoic (e.g., Strel'na and Tiksheozero belts), can contain gold deposits of Paleoproterozoic age.

The metamorphic grade of rocks in the studied deposits varies from greenschist to upper amphibolite facies, but the mineralized rocks are mainly metamorphosed at lower amphibolite grade, close to the transition from greenschist to amphibolite facies (deposits in the Kolmozero-Voron'ya, Strel'na, South Pechenga belts, and at the eastern flank of the Salla-Kuolajarvi belt). This level of metamorphism is considered as the most favorable for formation of gold deposits in metamorphic complexes.

Our study of fluid inclusions in quartz showed that fluids are mainly of $\mathrm{H}_{2} \mathrm{O}-\mathrm{CO}_{2}$ composition, but salinity differs from one deposit to another. Fluids with low salinity are believed to be of metamorphic origin (Nyal'm deposit, Porojarvi gold occurrence), and fluids with high salinity (Mayskoe, Oleninskoe) are probably related to an undefined magmatic source.

Author Contributions: Methodology: A.A.K.; conceptualization: A.A.K., O.V.K., V.I.B.; archive data collecting: V.I.B.; study of fluid inclusions: V.Yu.P., original draft writing: A.A.K., O.V.K., V.I.B.; editing and review: A.A.K.

Funding: The work was carried out under Project 0226-2019-0053 of the Russian Academy of Sciences.

Acknowledgments: The authors thank Yevgeny Savchenko and Yekaterina Selivanova (GI KSC RAS) for microprobe and X-ray study of minerals, and Tatiana Kaulina and Dmitry Zozulya for helpful discussion of the results. The authors are grateful to the reviewers for their comments, which helped to improve the manuscript.

Conflicts of Interest: The authors declare no conflict of interest.

\section{References}

1. State Report 'On Statute and Exploitation of Mineral Resources of Russian Federation in 2015'. Available online: http://www.mnr.gov.ru/docs/gosudarstvennye_doklady/o_sostoyanii_i_ispolzovanii_mineralno_ syrevykh_resursov_rossiyskoy_federatsii/ (accessed on 16 September 2018). (In Russian)

2. Subbotin, V.V.; Gabov, D.A.; Korchagin, A.U.; Savchenko, Y.E. Gold and Silver in the Composition of PGE Ores of the Fedorov-Pana Layered Intrusive Complex. Herald Kola Sci. Centre RAS 2017, 1, 53-65. (In Russian) 
3. Ward, M.; Kalinin, A.; McLaughlin, D.; Voytekhovich, V. Kola Mining Geological Company Ltd (KMGC)-Prospecting for PGE in the East Pansky layered massif. In The Neighborhood Cooperation and Eperience Exchange of Geological Prospecting and Survey of PGE Deposits in the Northern Fennoscandia; KNTs RAN: Apatity, Russia, 2008; pp. 52-55.

4. Eilu, P.; Rasilainen, K.; Halkoaho, T.; Huovinen, I.; Karkkainen, N.; Kontoniemi, O.; Lepisto, K.; Niiranen, T.; Sorjonen-Ward, P. Quantitative Assessment of Undiscovered Resources in Orogenic Gold Deposits in Finland; Report of Investigation 216; Geological Survey of Finland: Espoo, Finland, 2015; 318p, ISBN 978-952-217-331-7.

5. Rasilainen, K.; Eilu, P.; Halkoaho, T. Assessment of undiscovered metal resources in Finland. Ore Geol. Rev. 2017, 86, 896-923. [CrossRef]

6. Suurikuusikko Mineral Deposit Report. Geological Survey of Finland. Available online: http://tupa.gtk.fi/ karttasovellus/mdae/raportti/386_Suurikuusikko.pdf (accessed on 22 June 2018).

7. Eilu, P.; Pankka, H. Fingold-A Public Database on Gold Deposits in Finland; Geological Survey of Finland: Espoo, Finland, 2013; Available online: http:/ / en.gtk.fi/informationservices/palvelukuvaukset/fingold. html (accessed on 21 March 2016).

8. Mints, M.V.; Suleimanov, A.K.; Babayants, P.S. Deep Structure, Evolution, and Minerals in the Early Precabrian Basement of the East European Platform: Interpretation of Materials on Referent Profile 1-EV, Profiles $4 V$ and TATSEIS; GEOKART GEOS: Moscow, Russia, 2010; ISBN 978-5-89118-531-9. (In Russian)

9. Sundblad, K. Metallogeny of Gold in the Precambrian of Northern Europe. Econ. Geol. 2003, 98, 1271-1290. [CrossRef]

10. Eilu, P. (Ed.) Mineral Deposits and Metallogeny of Fennoscandia; Special Paper; Geological Survey of Finland: Espoo, Finland, 2012; Volume 53, 401p, ISBN 978-952-217-175-7.

11. Borisenko, A.S. Cryometric study of salt composition of the gas-liquid inclusions in minerals. Geol. Geofiz. 1977, 8, 16-27.

12. Bodnar, R.J.; Vityk, M.O. Interpretation of microterhmometric data for $\mathrm{H}_{2} \mathrm{O}-\mathrm{NaCl}$ fluid inclusions. In Fluid Inclusionsin Minerals: Methods and Applications; Benedetto DeVivo \& Maria Luce Frezzotti, Pontignano: Siena, Italy, 1994; pp. 117-130.

13. Collins, P.L.P. Gas hydrates in $\mathrm{CO}_{2}$-bearing fluid inclusions and the use of freezing data for estimation of salinity. Econ. Geol. 1979, 74, 1435-1444. [CrossRef]

14. Brown, P. FLINCOR: A computer program for the reduction and investigation of fluid inclusion data. Am. Mineral. 1989, 74, 1390-1393.

15. Daly, J.S.; Balagansky, V.V.; Timmerman, M.J.; Whitehouse, M.J. The Lapland-Kola orogen: Palaeoproterozoic collision and accretion of the northern Fennoscandian lithosphere. Geol. Soc. Lond. Mem. 2006, 32, 579-598. [CrossRef]

16. Korovkin, V.A.; Turyleva, L.V.; Rudenko, D.G.; Zhuravlev, V.A.; Klyuchnikova, G.N. Underground of the North-West of Russian Federation; VSEGEI: Sankt-Peterburg, Russia, 2003; 754p. (In Russian)

17. Kalinin, A.A.; Savchenko, Y.E.; Selivanova, Y.A. Minerals of precious metals in the Oleninskoe gold deposit (Kola peninsula). Zapiski RMO 2017, 146, 43-58. (In Russian)

18. Ovoca Gold plc Operational Update 13/09/2007. Available online: http:/ / www.ovocagold.com/upload/ 20070913_ayax_kola_\&_goltsovoye_update.pdf (accessed on 2 April 2017).

19. Volkov, A.V.; Novikov, I.A. The Oleninskoe gold sulfide deposit (Kola peninsula, Russia). Geol. Ore Deposits 2002, 44, 361-372.

20. Kudryashov, N.M.; Kalinin, A.A.; Lyalina, L.M.; Serov, P.A.; Elizarov, D.V. Geochronological and isotope geochemical characteristics of rocks, hosting gold occurrences in the Archean greenstone belt Kolmozero-Voron'ya (Kola region). Lithosphere 2015, 6, 83-100. (In Russian)

21. Kudryashov, N.M.; Lyalina, L.M.; Apanasevich, E.A. Age of rare metal pegmatites from the Vasin Myl'k deposit (Kola region): Evidence from of U-Pb geochronology of microlite. Dokl. AN 2015, 461, 321-325. [CrossRef]

22. Prokofiev, V.Y.; Kalinin, A.A.; Lobanov, K.V.; Banks, A.A.; Borovikov, D.A.; Chicherov, M.V. Composition of Fluids Responsible for Gold Mineralization in the Pechenga Structure of the Pechenga-Imandra-Varzuga Greenstone Belt, Kola Peninsula, Russia. Geol. Ore Depos. 2018, 60, 277-299. [CrossRef]

23. Safonov, Yu.G.; Volkov, A.V.; Vol'fson, A.A.; Genkin, A.D.; Krylova, T.L.; Chugaev, A.V. The Maysk quartz gold deposit (Northern Karelia): Geological, mineralogical, and geochemical studies and some genetic problems. Geol. Ore Depos. 2003, 45, 375-394. 
24. Gavrilenko, B.V. Minerageny of Precious Metals and Diamonds in the North-Eastern Part of the Baltic Shield. Ph.D. Thesis, Moscow University, Moscow, Russia, 2003.

25. Kalinin, A.A.; Galkin, N.N. The Precambrian Copper-Molybdenum porphyry deposit Pellapahk (Kolmozero-Voron'ya greenstone belt). Vestnik KNTs RAN 2012, 44, 80-92. (In Russian)

26. Kalinin, A.A.; Kazanov, O.V.; Kudryashov, N.M.; Bakaev, G.F.; Petrov, S.V.; Elizarov, D.V.; Lyalina, L.M. New promising gold objects in the Strelna greenstone belt, Kola Peninsula. Geol. Ore Depos. 2017, 59, 453-481. [CrossRef]

27. Bibikova, E.V.; Bogdanova, S.V.; Glebovitsky, V.A.; Claesson, S.; Skiöld, T. Evolution of the Belomorian belt: NORDSIM U-Pb zircon dating of the Chupa paragneisses, magmatism, and metamorphic stages. Petrology 2004, 12, 195-210.

28. Kalinin, A.A.; Astaf'ev, B.Y.; Voinova, O.A.; Bayanova, T.B.; Khiller, V.V. Geological structure and prospects for minerals of the Tiksheozero greenstone belt. Lithosphere 2017, 17, 102-126. (In Russian) [CrossRef]

29. Starostin, V.I.; Pelymskiy, G.A.; Leonenko, E.I.; Sakiya, D.R. Gold in BIF deposits of the East European platform. Izvestiya RAEN 2005, 14, 27-42. (In Russian)

30. Golikov, N.N.; Goryainov, P.M.; Ivanyuk, G.Y.; Pahomovskiy, Ya.A.; Yakovenchuk, V.N. Auriferous iron formations of the Olenegorsk deposit (Kola Peninsula, Russia). Geol. Ore Depos. 1999, 41, 144-151.

31. Bazay, A.V.; Ivanyuk, G.Y. Native metals in the rocks of BIF in the Kola Peninsula. Zapiski RMO 2008, 5, 34-47. (In Russian)

32. Ivanyuk, G.Y.; Bazay, A.V.; Pakhomovskiy, Y.A.; Yakovenchuk, V.N.; Goryainov, P.M. Low temperature hydrothermal veins in the rocks of the Archean ferriferrous formation. Zapiski VMO 2001, 3, 16-28. (In Russian)

33. Goryainov, P.M.; Ivanyuk, G.Y.; Bayanova, T.B.; Bazay, A.V.; Astaf'ev, B.Y.; Voinova, O.A. Composition, genesis, and age of rare-earth and precious metal mineralization in the rocks of banded iron formation in the Kola Peninsula. Proc. Fersman Sci. Sess. 2012, 9, 235-238. (In Russian)

34. Melezhik, V.A.; Sturt, B.A. General geology and evolutionary of the early Proterozoic Polmak-PasvikPechenga-Imandra/Varzuga-Ust'Ponoy Greenstone Belt in the northeastern Baltic Shield. Earth Sci. Rev. 1994, 36, 205-241. [CrossRef]

35. Duk, G.G. Structural Metamorphic Evolution of the Rocks in the Pechenga Complex; Nauka: Moscow-Leningrad, Russia, 1977; 104p. (In Russian)

36. Ahmedov, A.M.; Voron'yaeva, L.V.; Pavlov, V.A.; Krupenik, V.A.; Kuznetsov, V.A.; Sveshnikova, K.Yu. Gold mineralization in the Southern-Pechenga structural zone (Kola Peninsula): Types of occurrences and prospects for finding economic gold grades. Region. Geol. Metall. 2004, 20, 139-151. (In Russian)

37. Voron'yaeva, L.V. Geology and Gold Mineralization in the Southern Pechenga Structural Zone. Ph.D. Thesis, VSEGEI, Sankt-Peterburg, Russia, 2008. (In Russian)

38. Kalinin, A.A.; Bayanova, T.B.; Lyalina, L.M.; Serov, P.A.; Elizarov, D.V. Occurrences of gold mineralization in the Southern Pechenga structural zone: New isotope geochronological data. In Geology and Geochronology of the Rock-Forming and Ore Processes in Crystalline Shields, Proceedings of All-Russian (with International Participation) Conference, Apatity, Russia, 8-12 July 2013; K \& M: Apatity, Russia, 2013; pp. 69-71. (In Russian)

39. Bushmin, S.A.; Belyatskiy, B.V.; Krymskiy, R.Sh.; Glebovitskiy, V.A.; Buyko, A.K.; Savva, E.V.; Sergeev, S.A. Isochron Re-Os age of gold from Mayskoe gold-quartz vein deposit (Northern Karelia, Baltic Shield). Dokl. AN 2013, 448, 54-57. [CrossRef]

40. Balashov, Y.A. Geochronology of the Early Proterozoic rocks of the Pechenga-Varzuga structure in the Kola Peninsula. Petrology 1995, 4, 3-25. (In Russian)

41. Kulikov, V.S.; Kulikova, V.V. The Kuolajarvi synclinorium: A new view on the geological structure and combined cross section. In Trudy Karel'skogo Nauchnogo Tsentra RAN; Russian Academy of Sciences: Petrozavodsk, Russia, 2014; pp. 28-38. (In Russian)

42. Vol'fson, A.A.; Rusinov, V.L.; Krylova, T.L.; Chugaev, A.V. Metasomatic alterations in Precambrian metabasites of the Salla-Kuolajarvi graben near the Mayskoe gold field, Northern Karelia. Petrology 2005, 13, 161-186.

43. Gavrilenko, B.V.; Rezhenova, S.A. Ore minerals in gold-bearing quartz vein zones. In Mineral'nye ParageNezisy Metamorficheskih i Metasomaticheskih Porod (Mineral Paragenesis in Metamorphic and Metasomatic rocks); Kola Filial AN SSSR: Apatity, Russia, 1987; pp. 58-67. (In Russian) 
44. Kalinin, A.A.; Karpov, S.M.; Kalachyova, A.B.; Savchenko, Y.E. New data on mineralogy of the Mayskoe gold-quartz deposit (Northern Karelia). In Trudy Fersmanovskoy Nauchnoy Sessii GI KNTs RAN (Proceedings of the Fersman Scientific Session); Kola Scientific Center of RAS: Apatity, Russia, 2018; pp. 172-175. (In Russian)

45. Vol'fson, A.A.; Chugaev, A.V.; Safonov, Y.G.; Rusinov, V.L.; Krylova, T.L. Results of Rb-Sr, Rb-Rb study of gold field Mayskoe, Northern Karelia. In Isotope Dating of Geological Processes: New Methods and Results: Abstracts of Russian Conference, Moscow, Russia, 15-17 November 2000; GEOS: Moscow, Russia, 2000; pp. $93-96$. (In Russian)

46. Phillips, G.N.; Powell, R. Formation of gold deposits: A metamorphic devolatilization model. J. Metamorph. Geol. 2010, 28, 689-718. [CrossRef]

47. Belyaev, O.A.; Bushmin, S.A.; Voinov, A.S.; Volodichev, O.I.; Glebovitsky, V.A. Map of Mineral Facies of Metamorphic Rocks in the Eastern Baltic Shield in the Scale 1:1 500 000; Glebovitskiy, V.A., Ed.; VSEGEI, IPGGRAS: Sankt-Peterburg, Russia, 1991.

48. Zhu, Y.; An, F.; Tan, J. Geochemistry of hydrothermal gold deposits: A review. Geosci. Front. 2011, 2, 367-374. [CrossRef]

49. Pokrovski, G.S.; Akinfiev, N.N.; Borisova, A.Y.; Zotov, A.V.; Kouzmanov, K. Gold speciation and transport in geological fluids: Insights from experiments and physical-chemical modeling. Geol. Soc. Lond. Spec. Publ. 2014, 402, 9-70. [CrossRef]

50. Toulmin, P.; Barton, P.B. A thermodynamic study of pyrite and pyrrhotite. Geochim. Cosmochim. Acta 1964, 28, 641-671. [CrossRef]

51. Goldfarb, R.J.; Groves, D.I.; Gardoll, S. Orogenic Gold and geologic time: A global synthesis. Ore Geol. Rev. 2001, 18, 1-75. [CrossRef]

52. Rasilainen, K.; Eilu, P.; Halkoaho, T.; Iljina, M.; Karinen, T. Quantitative mineral resource assessment of undiscovered PGE resources in Finland. Ore Geol. Rev. 2010, 38, 270-287. [CrossRef]

(C) 2019 by the authors. Licensee MDPI, Basel, Switzerland. This article is an open access article distributed under the terms and conditions of the Creative Commons Attribution (CC BY) license (http:/ / creativecommons.org/licenses/by/4.0/). 